Article

\title{
Seasonal Variation of Glucosinolate Hydrolysis Products in Commercial White and Red Cabbages (Brassica oleracea var. capitata)
}

\author{
Nicole S. Wermter ${ }^{1,2}$, Sascha Rohn ${ }^{2,3}$ and Franziska S. Hanschen $1, *$ (i) \\ 1 Plant Quality and Food Security, Leibniz-Institute of Vegetable and Ornamental Crops (IGZ), \\ Theodor-Echtermeyer-Weg 1, 14979 Grossbeeren, Germany; nicolewermter@yahoo.de \\ 2 Hamburg School of Food Science, Institute of Food Chemistry, University of Hamburg, Grindelallee 117, \\ 20146 Hamburg, Germany; rohn@chemie.uni-hamburg.de \\ 3 Department of Food Chemistry and Analysis, Institute of Food Technology and Food Chemistry, \\ Technische Universität Berlin, TIB 4/3-1, Gustav-Meyer-Allee 25, 13355 Berlin, Germany \\ * Correspondence: hanschen@igzev.de
}

Received: 26 October 2020; Accepted: 12 November 2020; Published: 17 November 2020

\begin{abstract}
Brassica vegetables contain glucosinolates, which are well-known for their potential to form health-promoting isothiocyanates. Among those crucifers, white and red cabbage are commonly consumed vegetables, exhibiting different glucosinolate and hydrolysis profiles thereof. Regarding the health beneficial effects from these vegetables, more information, especially concerning the seasonal variation of glucosinolate profiles and the formation of their bioactive hydrolysis products in commercial cabbages, is needed. In this study, glucosinolates and glucosinolate hydrolysis product profiles in red and white cabbages from three different food retailers were monitored over six different sampling dates across the selling season in autumn. For the first time, it was shown that, while glucosinolate profiles were similar in each cabbage variety, glucosinolate hydrolysis product profiles and hydrolysis behavior varied considerably over the season. The highest total isothiocyanate concentrations were observed in conventional red $(1.66 \mu \mathrm{mol} / \mathrm{g} \mathrm{FW})$ and organic white $(0.93 \mu \mathrm{mol} / \mathrm{g}$ FW) cabbages purchased at the first sampling date in September. Here, red cabbage was with up to $1.06 \mu \mathrm{mol} / \mathrm{g} \mathrm{FW}$ of 4-(methylsulfinyl)butyl isothiocyanate (sulforaphane), an excellent source for this health-promoting isothiocyanate. Cabbages purchased 11 weeks later in autumn released lower levels of isothiocyanates, but mainly nitriles and epithionitriles. The results indicate that commercial cabbages purchased in early autumn could be healthier options than those purchased later in the year.
\end{abstract}

Keywords: glucosinolate; cabbage; isothiocyanate; epithionitrile; nitrile; Brassica; seasonal variation; food retailer

\section{Introduction}

With a consumption of $5.2 \mathrm{~kg} /$ person and year in 2017/2018, red cabbage (Brassica oleracea var. capitata f. rubra) and white cabbage (Brassica oleracea var. capitata f. alba) are the most consumed Brassicaceae vegetables in Germany, contributing to $5 \%$ of total vegetable intake [1]. These vegetables are rich in glucosinolates (GLSs), secondary, sulfurous plant constituents, which are particularly present in vacuoles of plant cells of the Brassicaceae family. The chemical GLS structure is determined by the nature of the side chain, depending on the amino acid inserted during biosynthesis [2,3] and GLSs typically contain a glucose unit, bound with a central carbon atom with nitrogen grouping via a thioether bridge. The carbon atom, in turn, is linked to a sulfate group and an organic aglycone residue, possessing an alkyl, alkenyl, aryl, or indole group [2]. This organic residue is inherent to the GLS, its chemical properties and its flavor, respectively [4,5]. Upon attack by herbivores or 
due to cutting or chopping of vegetables rich in GLSs, GLSs, which were previously present in spatially separated cell vacuoles, are hydrolyzed by myrosinase to various herbivore-toxic degradation products [6,7]. Hydrolysis by myrosinase occurs due to enzymatic cleavage of the thioglycoside bond, first resulting in an unstable aglucone (thiohydroximate-O-sulfate). The aglucone can then undergo a Lossen-like rearrangement to form isothiocyanates (ITCs) or decompose into nitriles and molecular sulfur. Moreover, in the presence of certain proteins such as the epithiospecifier protein (ESP), an aglycone with a terminal double bond favors epithionitrile (ETN) formation [7].

Consumption of ITCs can positively affect human health as they have antimicrobial, antidiabetogenic, chemopreventive, and anticarcinogenic properties [8,9]. Previous studies have shown a positive correlation between ITC uptake and cancer prevention $[8,10,11]$, and especially 4-(methylsulfinyl)butyl ITC (sulforaphane; 4MSOB-ITC) is valued for its anticarcinogenic potential [8]. Simple nitriles and ETNs on the other hand, seem to have less health beneficial effects [12,13]. Studies have elucidated that Brassica vegetables, not only ITCs, but also nitriles and ETNs can be the most predominant degradation products $[14,15]$. Consequently, in order to estimate the health beneficial potential of Brassica vegetables, it is of great importance to not only analyze intact GLSs, but also their behavior during hydrolysis.

The natural GLS content in vegetables varies in accordance with genotype, plant developmental step, soil and cultivation conditions, and other ecophysiological influences, but it is also affected by storage $[14,16,17]$. Moreover, GLS levels vary over the growth season and several studies reported higher GLS levels in B. oleracea plants grown in spring compared to plants grown in autumn [17], while in broccoli (B. oleracea var. italica), GLS levels were higher when grown in the summer season compared to the spring season [18]. Similarly, Nuñez-Gómez et al. (2020) recently reported higher GLS levels in broccoli grown in autumn compared to broccoli grown in the spring season. Moreover, when comparing two spring seasons, the one with less rainy days and higher temperature resulted in higher GLS levels [19]. Experiments performed under controlled conditions indicate that temperature, as well as day length affect GLS biosynthesis in B. oleracea in a structure-dependent way [20-22].

In order to predict GLS-based health beneficial properties, more information especially concerning GLS profiles and especially on their hydrolysis behavior in Brassica foods available for the consumer, is needed. Possessing a long harvesting period-typically ranging from June to November-red and white cabbages are facing seasonal changes and different ecophysiological influences, which can have a great impact on the GLS profile $[16,20]$ and might also affect the potential to form health-preventive ITC. To date, little is known about how GLS hydrolysis products are affected by different cultivation conditions. No revealing insight has been given on how GLS, and even more importantly, the formation behavior of their hydrolysis products varies in commercial cabbages across the whole season. Therefore, the objective of this study was to monitor the variation of GLS levels and the formation of their bioactive hydrolysis products in commercial red and white cabbage heads obtained from three local retailers in Germany and to link the data with the cultivation practices and post-harvest storage conditions.

\section{Materials and Methods}

\subsection{Chemicals}

Allyl GLS (Allyl; $\geq 99 \%$, reference compound), 4-hydroxybenzyl GLS (4OHbenzyl; purity $\geq 99 \%$, internal standard), and methylene chloride (GC Ultra Grade, solvent) were purchased from Carl Roth $\mathrm{GmbH}$ and Co. KG (Karlsruhe, Germany). Allyl ITC (Allyl-ITC; $\geq 99 \%$, reference compound), benzonitrile ( $\geq 99.9 \%$, internal standard), DEAE-Sephadex A-25 (anion exchanger), and the reference compounds 3-butenenitrile (Allyl-CN; $\geq 98 \%$ ), 4-pentenenitrile (3But-CN; $\geq 97 \%$ ), 3-phenylpropanenitrile ( $\geq 99 \%)$, were obtained from Sigma-Aldrich Chemie $\mathrm{GmbH}$ (Steinheim, Germany). The reference compounds 3-butenyl ITC (3But-ITC; $\geq 95 \%$ ) and 4-pentenyl ITC ( $\geq 95 \%)$ were purchased from TCI Deutschland GmbH (Eschborn, Germany). 3-(Methylsulfinyl)propyl ITC (3MSOP-ITC) and 4-(methylsulfanyl)butyl ITC (4MTB-ITC; $\geq 98 \%$ ) 
were purchased from Santa Cruz Biotechnology (Heidelberg, Germany). 4-(Methylsulfinyl)butyl ITC (4MSOB-ITC) was purchased from Enzo Life Sciences GmbH (Lörrach, Germany). The ETN 1-cyano-2,3-epithiopropane (CETP; $\geq 95 \%$ ) was synthesized by Taros Chemicals $\mathrm{GmbH}$ and Co. KG (Dortmund, Germany) and 1-cyano-3,4-epithiobutane (CETB; $\geq 95 \%$ ) was synthetized by ASCA GmbH Angewandte Synthesechemie Adlershof (Berlin, Germany). 5-(Methylsulfanyl)pentanenitrile (4MTB-CN) and 5-(methylsulfinyl)pentanenitrile (4MSOB-CN) were purchased from Enamine (SIA Enamine, Latvia, Riga). 3-Butenyl GLS (3But; $\geq 95 \%)$, 2(R)-hydroxy-3-butenyl GLS (2OH3But; $\geq 98 \%$ ), 4-(methylsulfanyl)butyl GLS (4MTB; $\geq 98 \%$ ), 4-(methylsulfinyl)butyl GLS (4MSOB; $\geq 98 \%$ ), 3-(methylsulfinyl)propyl GLS (3MSOP; $\geq 98 \%$ ), and 2-phenylethyl GLS (2PE; $\geq 98 \%$ ) were acquired from Phytolab GmbH and Co. KG, Vestenbergsgreuth, Germany. The solvents methanol ( $\geq 99.95 \%)$, acetonitrile (LC-MS grade), and arylsulfatase (enzyme) were purchased from Th. Geyer $\mathrm{GmbH}$ and Co. KG (Renningen, Germany).

\subsection{Plant Material}

Three red cabbages (Brassica oleracea convar. capitata var. rubra L.) and three white cabbages (Brassica oleracea convar. capitata var. alba) were purchased at regular intervals from the same two local conventional supermarkets $\left(\mathrm{CON}_{1}, \mathrm{CON}_{2}\right)$ and from the same organic supermarket $\left(\mathrm{ORG}_{1}\right)$ in Brandenburg, Germany over a period of 3 months (September-November 2019). The supermarkets were selected with regard to different German food trading companies. The two conventional supermarkets selected belong to the two biggest food trading companies in Germany and the organic supermarket also belongs to a big organic food supermarket chain. The exact sampling dates (S1-S6) are given in Table 1. Additionally, red and white cabbage heads, grown in the field at the Leibniz-Institute of Vegetable and Ornamental Crops (IGZ) in Grossbeeren, Germany, were harvested freshly in order to compare GLSs and their hydrolysis products with commercial cabbages. Therefore, red (cultivar 'Redma RZ F1') and white (cultivar 'Dottenfelder Dauer') cabbage seeds were sown (13.06.2019 and 20.06.2019) on loamy soil ( $\mathrm{pH} 7.3$ ) and then grown for 3 months at the IGZ (52 $\left.20^{\prime} 59.0^{\prime \prime} \mathrm{N} 13^{\circ} 18^{\prime} 57.5^{\prime \prime} \mathrm{E}\right)$. The red cabbage was cultivated with $100 \%$ of the required nitrogen level and fertilized using calcium ammonium nitrate and Patentkali ${ }^{\circledR}(419 \mathrm{~kg} \mathrm{~N} / \mathrm{ha}$ ). Before cultivation, the field was fertilized once with calcium ammonium nitrate $(\mathrm{CAN})$ and Patentkali ${ }^{\circledR}$ and later fertilized a second time, with CAN only during the cultivation period. In total, $377.78 \mathrm{~kg}$ CAN/ha and $40.74 \mathrm{~kg}$ Patentkali ${ }^{\circledR}$ were applied for fertilization.

For white cabbage, Aminofert ${ }^{\circledR}$ Vinasse fertilizer (BayWa AG, Munich, Germany) was applied $(60 \mathrm{~kg} \mathrm{~N} / \mathrm{ha}$ ) with $30 \%$ of the required nitrogen level. Here, fertilization occurred before the sowing of the seeds on 06 June 2019 and a second time on 25 June 2019 for head formation. The origin and cultivation background of commercial cabbages were investigated by interrogating service staff at supermarkets and by contacting growers. Cabbages sold at $\mathrm{CON}_{1}$ and $\mathrm{ORG}_{1}$ were procured from different farming areas in northern Germany $\left(\mathrm{CON}_{1}\right.$ : Neuenkirchen and Helse (Schleswig-Holstein), Germany; $\mathrm{ORG}_{1}$ : Blankensee (Mecklenburg-Western Pomerania), Hedwigenkoog (Schleswig-Holstein), Vierlinden and Seeblick (Brandenburg, Germany), whereas cabbages purchased from $\mathrm{CON}_{2}$ could continuously be procured from the same farming area, but on different fields within a $30 \mathrm{~km}$ perimeter in Neuenkirchen, Schleswig-Holstein, Germany) (Table 2). With regard to the cultivars, mainly white cabbage varieties such as "Storema", "Lennox", "Marcello", and "Impala" and red cabbage varieties, especially "Futurima", "Rodima", "Bandolero", and "Klimaro" were cultivated in the Dithmarschen region (Helse, Neuenkirchen) for $\mathrm{CON}_{1}$ and $\mathrm{CON}_{2}$. Cultivars "Rodynda"(red cabbage) and "Dowinda" (white cabbage) were mainly cultivated in Hohennauen, Germany for $\mathrm{ORG}_{1}$. Early cabbage cultivars ("Marcello", "Bandolero") were likely purchased between 04 and 05 September 2019, whereas later cabbage cultivars ("Storema", “Lennox", "Impala", "Futurima”, "Klimaro", “Rodynda", "Dowinda") could be purchased between 09 September 2019 and 06 November 2019. 
Table 1. Overview of the dates of the purchased and harvested red and white cabbage heads.

\begin{tabular}{|c|c|c|c|}
\hline \multirow[b]{2}{*}{ Supplier } & \multirow[b]{2}{*}{ Abbreviation } & \multicolumn{2}{|c|}{ Date of Purchase } \\
\hline & & White Cabbage & Red Cabbage \\
\hline \multirow{6}{*}{$\mathrm{CON}_{1}$} & S1 & 04.09 .2019 & 04.09 .2019 \\
\hline & S2 & 16.09.2019 & 16.09.2019 \\
\hline & S3 & 30.09 .2019 & 30.09 .2019 \\
\hline & S4 & 21.10.2019 & 21.10.2019 \\
\hline & S5 & 04.11 .2019 & 04.11 .2019 \\
\hline & S6 & 18.11.2019 & 18.11.2019 \\
\hline \multirow{6}{*}{$\mathrm{CON}_{2}$} & S1 & 05.09.2019 & 05.09 .2019 \\
\hline & S2 & 16.09.2019 & 16.09.2019 \\
\hline & S3 & 30.09 .2019 & 30.09.2019/01.10.2019 \\
\hline & S4 & 21.10 .2019 & 21.10.2019/23.10.2019 \\
\hline & S5 & 04.11 .2019 & 4.11.2019/06.11.2019 \\
\hline & S6 & 18.11.2019 & 18.11.2019 \\
\hline \multirow{6}{*}{$\mathrm{ORG}_{1}$} & S1 & 09.09.2019 & 09.09.2019 \\
\hline & S2 & 19.09.2019 & 19.09.2019 \\
\hline & S3 & 01.10 .2019 & 01.10 .2019 \\
\hline & S4 & 23.10.2019 & 23.10.2019 \\
\hline & S5 & 06.11 .2019 & 06.11 .2019 \\
\hline & S6 & 20.11.2019 & 20.11.2019 \\
\hline \multirow{3}{*}{\multicolumn{2}{|c|}{ Fresh harvest from field (IGZ) }} & \multicolumn{2}{|c|}{ Date of harvest } \\
\hline & & White Cabbage & Red Cabbage \\
\hline & & 29.10.2019 & 10.10.2019 \\
\hline
\end{tabular}


Table 2. Total overview of the German origin, cultivation, and storage conditions of commercial red and white cabbages and red and white cabbages from the field experiment. Purchase dates of S1-S6 can be found in Table 1.

\begin{tabular}{|c|c|c|c|c|c|c|c|c|c|c|}
\hline Supplier & Origin of Cultivation & $\begin{array}{l}\text { Samples/Date } \\
\text { of Harvest } \\
\text { (IGZ) }\end{array}$ & $\begin{array}{l}\text { Harvest } \\
\text { Season }\end{array}$ & $\begin{array}{l}\text { Cabbage } \\
\text { Type }\end{array}$ & Cabbage Genotype & $\begin{array}{l}\text { Soil Type } \\
\text { and Field }\end{array}$ & Fertilizer & $\begin{array}{l}\text { Certifica-Tion } \\
\text { Mark }\end{array}$ & $\begin{array}{c}\text { Storage } \\
\text { Conditions } * 1\end{array}$ & $\begin{array}{c}\text { Storage } \\
\text { Conditions }{ }^{* 2}\end{array}$ \\
\hline \multirow{2}{*}{$\mathrm{CON}_{1}$} & \multirow{2}{*}{$\begin{array}{l}\text { 25792, Neuenkirchen } \\
\text { Schleswig-Holstein }\end{array}$} & S1-S3 & \multirow{2}{*}{$\begin{array}{l}\text { Summer, } \\
\text { autumn }\end{array}$} & \multirow{2}{*}{$(1),(2)$} & $\begin{array}{l}\text { White cabbage } \\
\text { hybrids }\end{array}$ & \multirow{2}{*}{ Sea marsh } & \multirow{2}{*}{$\begin{array}{l}\text { Urea, CAN, phosphate } \\
\text { and potash }\end{array}$} & \multirow{2}{*}{ QS } & \multirow[t]{2}{*}{ (i) } & \multirow{2}{*}{$20^{\circ} \mathrm{C}$ day/night } \\
\hline & & S1-S4 & & & Red cabbage hybrids & & & & & \\
\hline \multirow{2}{*}{$\mathrm{CON}_{1}$} & \multirow{2}{*}{$\begin{array}{c}\text { 25709, Helse } \\
\text { Schleswig-Holstein }\end{array}$} & S4-S6 & \multirow{2}{*}{$\begin{array}{l}\text { Autumn, } \\
\text { winter }\end{array}$} & \multirow{2}{*}{$(2),(3)$} & $\begin{array}{l}\text { White cabbage } \\
\text { hybrids }\end{array}$ & \multirow{2}{*}{$\begin{array}{l}\text { Sea marsh, } \\
\text { pH-value } \\
7.0-7.4\end{array}$} & \multirow{2}{*}{$\begin{array}{l}\text { PKS fertilizer (blends), } \\
\text { ammonium nitrate and } \\
\text { urea, calcium cyanamide }\end{array}$} & \multirow{2}{*}{ QS } & \multirow{2}{*}{ (ii) } & \multirow[t]{2}{*}{$20^{\circ} \mathrm{C}$ day/night } \\
\hline & & S5, S6 & & & Red cabbage hybrids & & & & & \\
\hline $\mathrm{CON}_{2}$ & $\begin{array}{l}\text { 25792, Neuenkirchen } \\
\text { Schleswig-Holstein }\end{array}$ & S1-S6 & $\begin{array}{l}\text { Summer, } \\
\text { autumn, } \\
\text { winter }\end{array}$ & $(1),(2),(3)$ & $\begin{array}{l}\text { Red and white } \\
\text { cabbage hybrids }\end{array}$ & Sea marsh & $\begin{array}{l}\text { Urea, CAN, phosphate } \\
\text { and potash }\end{array}$ & QS & (iii) & $\begin{array}{c}7-10^{\circ} \mathrm{C} \text { day/night } \\
\text { in cooling counter, } \\
\text { max. } 1 \text { week }\end{array}$ \\
\hline \multirow[t]{2}{*}{$\mathrm{ORG}_{1}$} & \multirow{2}{*}{$\begin{array}{c}\text { 17237, Blankensee } \\
\text { Mecklenburg-Western } \\
\text { Pomerania }\end{array}$} & S1, S4, S5 & \multirow[t]{2}{*}{ Autumn } & \multirow[t]{2}{*}{ (2) } & $\begin{array}{l}\text { White cabbage } \\
\text { hybrids }\end{array}$ & \multirow[t]{2}{*}{ Sandy loam } & \multirow[t]{2}{*}{ Hair-meal pellets } & \multirow[t]{2}{*}{ Bioland } & \multirow[t]{2}{*}{ (iv) } & \multirow{2}{*}{$\begin{array}{c}10^{\circ} \mathrm{C} \text { day/night in } \\
\text { cooling counter, } \\
\text { max. } 1 \text { week }\end{array}$} \\
\hline & & S1 & & & Red cabbage hybrids & & & & & \\
\hline \multirow[b]{2}{*}{$\mathrm{ORG}_{1}$} & \multirow{2}{*}{$\begin{array}{l}\text { 25761, Hedwigenkoog } \\
\text { Schleswig-Holstein }\end{array}$} & $\mathrm{S} 2, \mathrm{~S} 3$ & \multirow[b]{2}{*}{ Autumn } & \multirow[b]{2}{*}{ (2) } & $\begin{array}{c}\text { White cabbage, } \\
\text { non-hybrid }\end{array}$ & \multirow[b]{2}{*}{ Sea Marsh } & \multirow[b]{2}{*}{ Compost } & \multirow[b]{2}{*}{ Demeter } & \multirow[b]{2}{*}{ (iv) } & \multirow{2}{*}{$\begin{array}{l}\text { Day/night in } \\
\text { cooling counter, } \\
\text { max. } 1 \text { week }\end{array}$} \\
\hline & & $\mathrm{S} 2, \mathrm{~S} 3, \mathrm{~S} 4, \mathrm{~S} 5$ & & & $\begin{array}{l}\text { Red cabbage, } \\
\text { non-hybrid }\end{array}$ & & & & & \\
\hline ORG $_{1}$ & $\begin{array}{l}\text { 15306, Vierlinden } \\
\text { Brandenburg }\end{array}$ & S6 & Autumn & (2) & $\begin{array}{l}\text { White cabbage } \\
\text { hybrids }\end{array}$ & Sandy loam & Hair-meal pellets & Bioland & (v) & $\begin{array}{l}\text { Day/night in } \\
\text { cooling counter, } \\
\text { max. } 1 \text { week }\end{array}$ \\
\hline $\mathrm{ORG}_{1}$ & $\begin{array}{l}\text { 14715, Seeblick } \\
\text { Brandenburg }\end{array}$ & S6 & Autumn & (2) & $\begin{array}{l}\text { Red cabbage, } \\
\text { non-hybrids }\end{array}$ & Sandy loam & Compost & Demeter & (iv) & $\begin{array}{l}\text { Day/night in } \\
\text { cooling counter, } \\
\text { max. } 1 \text { week }\end{array}$ \\
\hline IGZ & $\begin{array}{l}\text { 14979, Großbeeren } \\
\text { Brandenburg }\end{array}$ & $\begin{array}{l}10 \text { October } \\
2019\end{array}$ & Autumn & (2) & $\begin{array}{l}\text { Red cabbage (Redma } \\
\text { RZ F1), hybrid }\end{array}$ & Silty loam & CAN, patentkali & - & No storage & No storage \\
\hline IGZ & $\begin{array}{l}\text { 14979, Großbeeren } \\
\text { Brandenburg }\end{array}$ & $\begin{array}{l}29 \text { October } \\
2019\end{array}$ & Autumn & (2) & $\begin{array}{c}\text { White cabbage } \\
\text { (Dottenfelder Dauer), } \\
\text { non-hybrid }\end{array}$ & Silty loam & Vinasse & - & No storage & No storage \\
\hline
\end{tabular}

$* 1$ Before selling, $* 2$ during selling; CAN-calcium ammonium nitrate. (i) $6-8{ }^{\circ} \mathrm{C}$ for $1-2$ days after harvest, storage for $1-2$ days (intermediate trade), then storage at $6-8{ }^{\circ} \mathrm{C}$ (cold storage warehouse). (1) Early cabbage (fresh harvest). (ii) $6-7^{\circ} \mathrm{C}$ for $1-2$ days in central warehouse. (2) Late cabbage (fresh harvest). (iii) $6-8{ }^{\circ} \mathrm{C}$ for $1-2$ days after harvest, then storage at $6-8^{\circ} \mathrm{C}$ in cold storage warehouse. (3) Long-term stored (stored). (iv) $2-6{ }^{\circ} \mathrm{C}$ for $1-2$ days after harvest, then storage at $4-7{ }^{\circ} \mathrm{C}$ for $1-3$ days in cold storage warehouse (max $48 \mathrm{~h}$ ). (v) $0.1-0.3{ }^{\circ} \mathrm{C}$ cold storage warehouse. 
Long-term stored white cabbages ('Storema", "Lennox", "Impala", "Dowinda") were purchased as of 18 November 2019 and stored at $0.1-0.3^{\circ} \mathrm{C}$ in warehouses at the wholesaler. Cabbages from $\mathrm{CON}_{1}$ and $\mathrm{CON}_{2}$ were fertilized using a combination of urea, calcium ammonium nitrate, phosphate and potassium, whilst organically cultivated cabbage $\mathrm{ORG}_{1}$ was fertilized using hair-meal pellets (200 kg N/ha) or compost (Table 2). According to growers in Blankensee, Neuenkirchen, Vierlinden, and Helse, only hybrid cultivars such as "Storema", "Impala", "Lennox", and "Bandolero" were grown, harvested, and later sold as ripe cabbages to $\mathrm{CON}_{1}$ and $\mathrm{CON}_{2}$, whereas non-hybrid cultivars such as "Rodynda" and "Dowinda" (grown for $\mathrm{ORG}_{1}$ ) were generally grown in Hedwigenkoog and Hohennauen. According to growers in Helse, seeds were sown from the 16th to the 20th calendar week of 2019, and cabbages were harvested from the 23rd to the 46th calendar week on heavy, sea marsh soil. Similar sowing and harvesting dates also applied for cabbages cultivated in Neuenkirchen, which were harvested between weeks 23 to 45 and also grown on heavy, sea marsh soil. According to growers in Helse, which supplied $\mathrm{CON}_{1}$ with cabbage, cabbage heads grown for the conventional market generally grew slower in the Dithmarschen region and were grown for $150 \mathrm{~d}$ in Helse on sea marsh soil (late cabbage). The growth of early cultivars ( $\mathrm{S} 1$ sampling of $\mathrm{CON}_{1}$ and $\mathrm{CON}_{2}$ ) was accelerated with non-woven fibre barriers. The alleged storage conditions, according to all growers before the selling period and conditions in the supermarket during selling time, according to salespersons in $\mathrm{CON}_{1}, \mathrm{CON}_{2}$, and $\mathrm{ORG}_{1}$ are listed in Table 2, while in Supplemental Table S1 all information collected during this study on the analyzed cabbages are given for each cabbage separately and in more detail.

In order to give a better understanding of how GLSs and their hydrolysis products can differ in commercial cabbages and how they might change within the season, GLSs and their hydrolysis products were additionally monitored by comparing cabbage heads from an organic and two conventional supermarkets $\left(\mathrm{ORG}_{1}, \mathrm{CON}_{1}, \mathrm{CON}_{2}\right)$ with cabbage heads grown at the Leibniz-Institute of Vegetable and Ornamental Crops (IGZ), Grossbeeren, Germany. A further aim of this work was to link the results with the common cultivation practices and the alleged storage conditions (Table 2).

\subsection{Sample Preparation}

Fresh cabbage heads were chopped in half. Of the two obtained halves, one of the halves was halved again, and two quarters were obtained. Afterwards, one of the obtained quarters was divided into 2-3 strips (weight: $70-180 \mathrm{~g}$, width: $1-1.5 \mathrm{~cm}$ ) along the middle, and the strips were frozen at $-20{ }^{\circ} \mathrm{C}$ overnight before lyophilization $(11 \mathrm{~d})$ and were later ground. The remaining plant material of the same quarter, from which the strips were obtained, was then cut into small pieces of $1 \mathrm{~cm}$ width. The chopped plant material was thoroughly mixed by hand, and $15-20 \mathrm{~g}$ fresh cabbage was then given into a round bottom glass vessel for homogenization. Afterwards, $15-20 \mathrm{~mL}$ of distilled water was added, in order to obtain a 1:1 ratio of plant material and water. Then, samples were homogenized for $1 \mathrm{~min}$ at a rate of 20,000 rpm using a mixer (H04, Edmund Bühler GmbH, Tübingen, Germany) and incubated for $1 \mathrm{~h}$ at room temperature $\left(22^{\circ} \mathrm{C}\right)$.

\subsection{Analysis of Glucosinolates}

To determine the profiles and concentrations of GLS in red and white cabbages, $10 \mathrm{mg}$ of lyophilized powder was extracted and GLS was analyzed as their desulfo-form [23]. Briefly, $10 \mathrm{mg}$ of dry plant powder was extracted thrice using $70 \%$ of hot methanol in the presence of $0.025 \mu \mathrm{mol}$ 4-hydroxybenzyl GLS as an internal standard. The extracts were combined and desulfated on a DEAE-Sephadex A-25 ion-exchanger column using aryl sulfatase. Afterwards, desulfo-GLSs were eluted with $1 \mathrm{~mL}$ of water and analyzed using an Agilent UHPLC-DAD-ToF-MS system equipped with a Poroshell 120 EC-C18 column $(100 \times 2.1 \mathrm{~mm}, 2.7 \mu \mathrm{m}$; Agilent Technologies), a gradient of water, and $40 \%$ acetonitrile, as described previously [23]. Desulfo-GLSs were quantified at $229 \mathrm{~nm}$ via the internal standard and the calibration factor reported in the DIN EN ISO 9167-1 and calculated on this basis for 4-hydroxybenzyl GLS. 


\subsection{Determination of Glucosinolate Breakdown Products}

For the analysis of GLS hydrolysis products released from red and white cabbage tissue, the protocol described by Hanschen and Schreiner (2017) was followed with small modifications [14]: Briefly, $500 \mathrm{mg}$ of the homogenized fresh samples (containing 50\% of water) were weighed into solvent resistant centrifuge tubes. During the first two samplings, $1 \mathrm{~g}$ of sample homogenate was used, which might have led to reduced recoveries for nitriles and epithionitriles, due to higher water to solvent ratio. Then, the internal standard benzonitrile $(0.2 \mu \mathrm{mol})$ was added and GLS hydrolysis products were extracted 3 times using methylene chloride: $2 \mathrm{~mL}$ during the first extraction and $1.5 \mathrm{~mL}$ of methylene chloride in the second and third extraction. Then, samples were analyzed as described previously [14], except that in the present study an Agilent J\&W VF-5ms GC-MS column $(30 \mathrm{~m} \times 0.25 \mathrm{~mm} \times 0.25 \mu \mathrm{m})$ coupled to a $10 \mathrm{~m}$ EZ-Guard P/N:CP9013 column was used for analyte separation.

\subsection{Statistical Analysis}

To investigate differences between different sampling dates (S1-S6), means were compared using ANOVA and Tukey's HSD test and STATISTICA version 13.5.0.17 software (TIBCO Software Inc., Palo Alto, CA, USA) with a significance level of $p \leq 0.05$. All analyses were carried out in triplicate by analyzing three biological replicates.

\section{Results}

Samples (three cabbage heads) from each of the three retailers (conventional supermarkets $\mathrm{CON}_{1}$, $\mathrm{CON}_{2}$, and organic supermarket $\mathrm{ORG}_{1}$ ) were collected between September and November 2019 every 2 to 3 weeks, summing up to a total of six sampling dates (S1-S6). GLS-profiles and the corresponding GLS hydrolysis products were monitored over the six sampling periods and additionally compared to fresh samples (four red and white cabbage heads) harvested from a field at the IGZ in Grossbeeren, Germany. Most analyzed cabbage heads differed in their regional origin and harvest time (Table 2). The dates of the purchased or harvested cabbages over the six sampling periods (S1-S6) are listed in Table 1.

\subsection{Glucosinolates in White and Red Cabbage from Local Food Retailers}

The GLS profile of the most abundant GLS of white cabbage purchased from the different food retailers over the 3-month period is given in Figure 1A-C, whilst the GLS profile for red cabbage is displayed in Figure 1D-F. Table 3 shows the chemical structures of the most abundant cabbage GLS, as well as their GLS hydrolysis product names including the abbreviations. In the heads of the analyzed white and red cabbage cultivars, a total of 12 chemically different GLSs were detected (Table S2). The main GLSs were allyl GLS (Allyl), 3-butenyl GLS (3But), 2-hydroxy-3-butenyl GLS (2OH3But), 3-(methylsulfinyl)propyl GLS (3MSOP), 4-(methylsulfinyl)butyl GLS (4MSOB), and indol-3-ylmethyl GLS (I3M) (Figure 1). The GLS profile in white and red cabbage cultivars between different supermarkets was often found to be similar within the same cabbage variety. In that way, Allyl, 3MSOP, and I3M were found to be most dominant in white cabbage, with maximum Allyl concentrations reaching $0.71 \pm 0.02 \mu \mathrm{mol} / \mathrm{g}$ FW in S5 (Figure 1A), up to $0.64 \pm 0.17 \mu \mathrm{mol} / \mathrm{g}$ FW 3MSOP in S1 of ORG 1 , and up to $0.49 \pm 0.12 \mu \mathrm{mol} / \mathrm{g}$ FW I3M in S4 of ORG 1 (Figure 1C). Red cabbage was often the richest in 2OH3But and 4MSOB (Figure 1D-F), with up to $0.99 \pm 0.19 \mu \mathrm{mol} / \mathrm{g}$ FW 2OH3But in S1 of $\mathrm{CON}_{1}$ (Figure 1D) and $0.93 \pm 0.05 \mu \mathrm{mol} / \mathrm{g}$ FW 4MSOB in $\mathrm{S} 1$ of $\mathrm{CON}_{1}$ (Figure 1D), respectively. However, Allyl, 3But, 3MSOP, and I3M were also formed in considerable amounts in red cabbage (Figure 1D-F). 
Table 3. Structures of main cabbage glucosinolates, their abbreviations, and their hydrolysis products analyzed in the present study. N.d.: Not detected.

\begin{tabular}{|c|c|c|c|c|c|c|c|c|}
\hline \multirow[b]{3}{*}{ Structure } & \multicolumn{2}{|c|}{ Glucosinolates (GLSs) } & \multicolumn{6}{|c|}{ Corresponding Breakdown Products } \\
\hline & & & \multicolumn{2}{|c|}{ Isothiocyanate (ITC) } & \multicolumn{2}{|r|}{ Nitrile } & \multicolumn{2}{|c|}{ Epithionitrile (ETN) } \\
\hline & Abbreviation & Name (trivial name) & Abbreviation & Name & Abbreviation & Name & Abbreviation & Name \\
\hline & Allyl & allyl GLS (sinigrin) & Allyl-ITC & 2-propenyl ITC & Allyl-CN & 3-butenenitrile & CETP & $\begin{array}{l}\text { 1-cyano-2,3- } \\
\text { epithiopropane }\end{array}$ \\
\hline & 3But & $\begin{array}{l}\text { 3-butenyl GLS } \\
\text { (gluconapin) }\end{array}$ & 3But-ITC & 3-butenyl ITC & 3But-CN & 4-pentenenitrile & CETB & $\begin{array}{l}\text { 1-cyano-3,4- } \\
\text { epithiobutane }\end{array}$ \\
\hline & 2OH3But & $\begin{array}{l}\text { 2-(R)-2-hydroxy-3- } \\
\text { butenyl GLS } \\
\text { (progoitrin) }\end{array}$ & OZT & $\begin{array}{l}\text { 5-vinyl-1,3- } \\
\text { oxazolidine-2-thione }\end{array}$ & & 3-hydroxy-pentenenitrile & $\begin{array}{l}\text { CHETB A } \\
\text { CHETB B }\end{array}$ & $\begin{array}{l}\text { 1-cyano-2-hydroxy- } \\
\text { 3,4-epithiobutane }\end{array}$ \\
\hline & 3MSOP & $\begin{array}{l}\text { 3-(methylsulfinyl)propyl } \\
\text { GLS (glucoiberin) }\end{array}$ & 3MSOP-ITC & $\begin{array}{l}\text { 3-(methylsulfinyl)- } \\
\text { propyl ITC }\end{array}$ & 3MSOP-CN & $\begin{array}{l}\text { 4-(methylsulfinyl)- } \\
\text { butanenitrile }\end{array}$ & - & - \\
\hline O & $4 \mathrm{MSOB}$ & $\begin{array}{l}\text { 4-(methylsulfinyl)butyl } \\
\text { GLS (glucoraphanin) }\end{array}$ & 4MSOB-ITC & $\begin{array}{l}\text { 4-(methylsulfinyl)butyl } \\
\text { ITC }\end{array}$ & $4 \mathrm{MSOB}-\mathrm{CN}$ & $\begin{array}{l}\text { 5-(methylsulfinyl)- } \\
\text { pentanenitrile }\end{array}$ & - & - \\
\hline & $\mathrm{I} 3 \mathrm{M}$ & $\begin{array}{l}\text { indol-3-ylmethyl GLS } \\
\text { (glucobrassicin) }\end{array}$ & & n.d. & & indole-3-acetonitrile & - & - \\
\hline
\end{tabular}


In general, red cabbage heads produced higher levels of GLSs (Figure 1D-F) compared to white cabbage heads (Figure 1A-C). The highest total GLS levels in red cabbage heads were detected in S1 from $\mathrm{CON}_{1}(3.12 \pm 0.27 \mu \mathrm{mol} / \mathrm{g} \mathrm{FW})$ (Figure 1D), whereas the highest total GLS content for white cabbage was observed in $\mathrm{S} 5$ from $\mathrm{CON}_{1}(1.61 \pm 0.11 \mu \mathrm{mol} / \mathrm{g} \mathrm{FW})$ (Figure 1A).

Whilst general increases in total GLS concentration were found from sampling S1 to S6 (especially due to Allyl) in white cabbages from $\mathrm{CON}_{2}$ (Figure 1B), a general decreasing trend in total GLS concentration was detected in white cabbages procured from $\mathrm{ORG}_{1}$ (Figure 1C). In red cabbage, total GLSs varied for the individual samples from the same food retailers in all purchased red cabbage heads (Figure 1D-F), and no specific trend was noted between purchase dates from the different retailers. With regard to individual GLSs, many GLSs in cabbages from the three supermarkets did not significantly change over the different sampling dates, such as GLSs in red cabbage from $\mathrm{CON}_{2}$ (Figure 1E), while others were affected (Figure 1).

The two major GLSs detected in white cabbage heads were 3MSOP and Allyl. In white cabbages procured from $\mathrm{CON}_{1}$ (S1-S6, Figure 1A), Allyl increased by 2.1-fold from S1 to S5 and then decreased in $\mathrm{S} 6$ to levels similar to $\mathrm{S} 1$. In white cabbages, which were purchased from $\mathrm{CON}_{2}$, a general increase in Allyl content was observed from S1 to S6 $(0.17 \pm 0.03$ to $0.61 \pm 0.07 \mu \mathrm{mol} / \mathrm{g} \mathrm{FW})$ (Figure 1B), while in white cabbages purchased from $\mathrm{ORG}_{1}$ (Figure 1C), Allyl did not significantly change over time. In red cabbage, no significant changes were observable for Allyl (Figure 1D-F). 3MSOP as the other main GLS of white cabbage stayed the same over the sampling period in cabbages from $\mathrm{CON}_{2}$ and $\mathrm{ORG}_{1}$, but displayed increased levels in $\mathrm{S} 4$ and $\mathrm{S} 5$ of cabbages from $\mathrm{CON}_{1}$ compared to the S1-S3 samples (Figure 1A). In red cabbage, 3MSOP did not change across the consecutive sampling dates (Figure 1D-F). 4MSOB as a major GLS in red cabbage displayed reduced content in S2-S4 compared to $\mathrm{S} 1$ in $\mathrm{CON}_{1}$-cabbage (Figure 1D), but did not change in cabbages from $\mathrm{CON}_{2}$ and $\mathrm{ORG}_{1}$. Likewise, in white cabbage of $\mathrm{ORG}_{1}, 4 \mathrm{MSOB}$ was not affected. In white cabbage from $\mathrm{CON}_{1}, 4 \mathrm{MSOB}$ slightly decreased from $\mathrm{S} 1$ to $\mathrm{S} 5$ but was highest in S6 (Figure 1A), and in $\mathrm{CON}_{2}$-cabbages, this GLS generally displayed similar levels over the sampling dates (Figure 1B). Similarly, 2OH3But varied significantly only in white and red cabbage procured from $\mathrm{CON}_{1}$ (Figure 1A,D), but not in cabbages from the other supermarkets. In $\mathrm{CON}_{1}$-cabbages, $2 \mathrm{OH} 3 \mathrm{But}$ was highest in $\mathrm{S} 1$ (red cabbage) or $\mathrm{S} 2$ (white cabbage) samples, then decreased until S4 (red cabbage) or S5 (white cabbage) and then again increased in the last samples (by tendency in red cabbage; significantly in white cabbage). The indole GLS I3M generally had similar levels over the different sampling dates in white and red cabbages, as well (Figure 1). 
A)

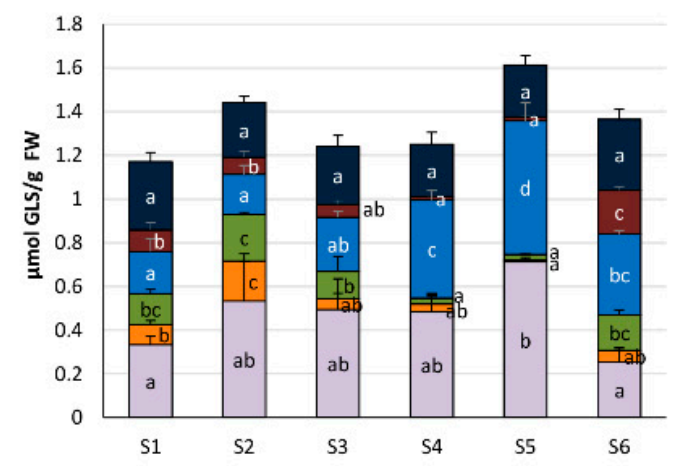

D)

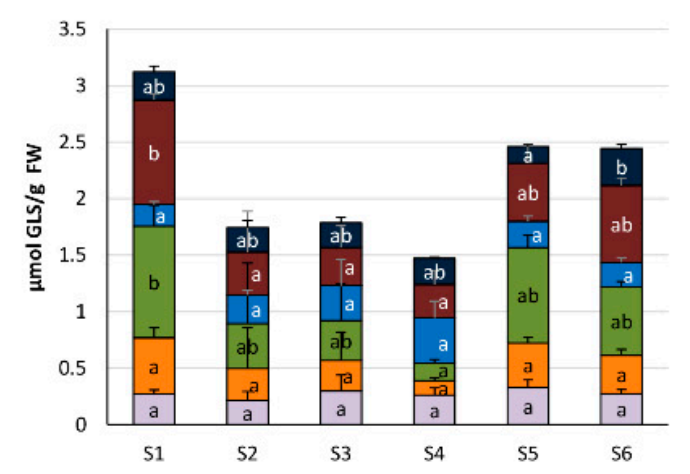

B)

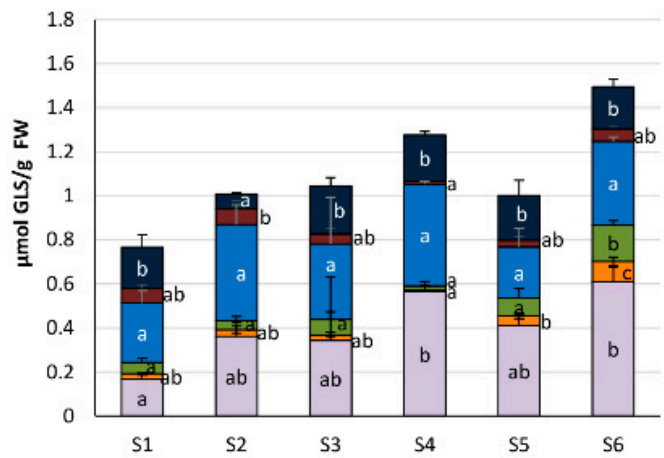

E)

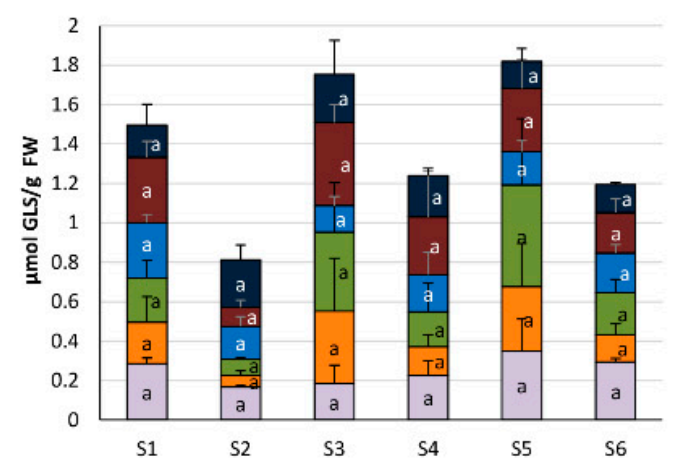

C)

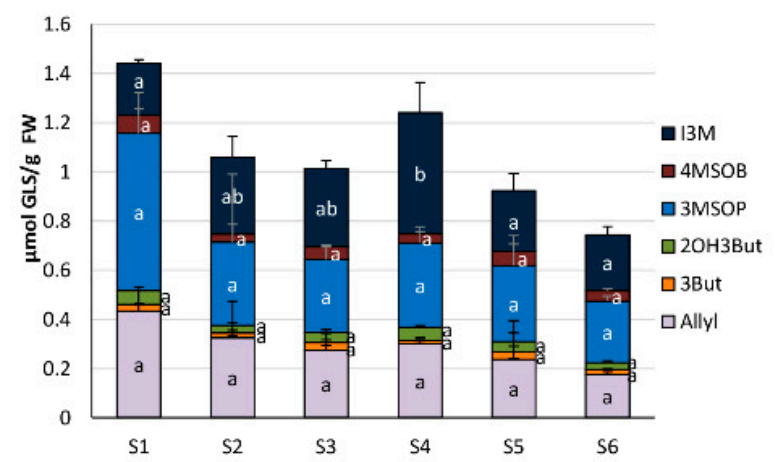

F)

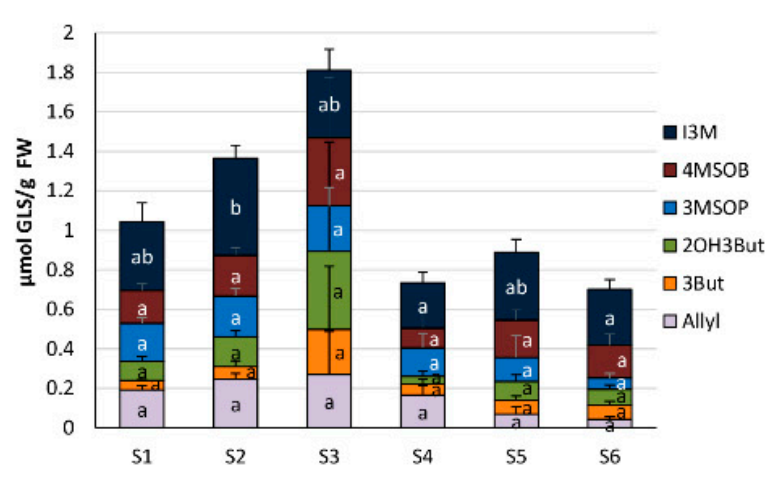

Figure 1. Glucosinolate (GLS) profile in white (A-C) and red cabbages (D-F) from conventional (A,B,D,E) and organic supermarkets (C,F) on different sampling dates (S1-S6). Exact sampling dates can be found in Table 1. A) and D) Represent conventional supermarket 1 (CON 1$)$, B) and E) stand for conventional supermarket 2 $\left(\mathrm{CON}_{2}\right)$, and $\left.\mathrm{C}\right)$ and $\left.\mathrm{F}\right)$ show results from organic supermarket $1\left(\mathrm{ORG}_{1}\right)$. Each color in the bar of the given bar chart represents the mean plus standard deviation (SD) of the GLSs from three cabbage heads from the same supermarket $(n=3)$. Lower case letters indicate significant differences in means between the levels of a GLS on different sampling dates, as tested by ANOVA and Tukey HSD test at the $p \leq 0.05$ level. Abbreviations: FW: Fresh weight; abbreviations of compounds as listed in Table 3. 


\subsection{Glucosinolate Hydrolysis Product Formation in White and Red Cabbages from Local Food Retailers}

Resulting from the homogenization of the fresh cabbage material, GLSs in cabbages from the different food retailers were degraded. The most pronounced GLS hydrolysis products released from white and red cabbages included the ITCs (or follow-up products from ITC) 3-(methylsulfinyl)propyl ITC (3MSOP-ITC), 4-(methylsulfinyl)butyl ITC (4MSOB-ITC), 3-butenyl ITC (3But-ITC), and 5-vinyloxazolidine-2-thione (OZT), the nitriles 5-(methylsulfinyl)pentanenitrile (4MSOB-CN) and 4-(methylsulfinyl)butanenitrile (3MSOP-CN) and the ETNs 1-cyano-2,3-epthiopropane (CETP), 1-cyano-3,4-epithiobutane (CETB), and isomers of 1-cyano-2-hydroxy-3,4-epithiobutane (CHETB A, CHETB B) (Table S3). Overall, the main GLS hydrolysis products in white cabbages were 3-MSOP-CN and 3MSOP-ITC, which were formed from 3MSOP and CETP, originating from the GLS Allyl (Figure 2A-C).

Red cabbages released mainly 4MSOB-CN and 4MSOB-ITC, originating from 4MSOB and CETP, but also 3MSOP-products and CETB and CHETB were often released in higher amounts (Figure 2D-F). Usually, homogenized red cabbages released more GLS-hydrolysis products compared to white cabbages (Figures 2 and 3). The formation of the cancer-preventive ITC 4MSOB-ITC was highest in red cabbages procured from $\mathrm{CON}_{1}$ in the $\mathrm{S} 1$ sample $(1.06 \pm 0.25 \mu \mathrm{mol} / \mathrm{g} \mathrm{FW})$, where it was also the main GLS-hydrolysis product. Although still being the main GLS-hydrolysis product in some samples, less 4MSOB-ITC was released in $\mathrm{CON}_{2}$ - and $\mathrm{ORG}_{1}$ - cabbages (up to $0.33 \pm 0.18 \mu \mathrm{mol} / \mathrm{g} \mathrm{FW}$ in S3 from $\mathrm{CON}_{2}$ and up to $0.44 \pm 0.16 \mu \mathrm{mol} / \mathrm{g} \mathrm{FW}$ in $\mathrm{S} 2$ from $\mathrm{ORG}_{1}$ ) (Figure 2D-F). The formation of GLS hydrolysis products in cabbages purchased from the three different supermarkets generally varied over the course of the sampling period (Figures 2 and 3). Overall, the S5 sample of red cabbages with $2.68 \pm 0.57 \mu \mathrm{mol} / \mathrm{g}$ FW displayed the highest total level of released GLS-hydrolysis products.

Regarding white cabbages, total ITC concentrations were highest with up to $0.50 \pm 0.19 \mu \mathrm{mol} / \mathrm{g} \mathrm{FW}$ in the later samples $\mathrm{S} 4$ and $\mathrm{S} 5$ from $\mathrm{CON}_{1}$, where they were also the main GLS hydrolysis product type. In addition, total nitrile levels were higher in these later samples. Total ETN levels were also highest in S5 (Figure 3A). In white cabbages from $\mathrm{CON}_{2}$, total ITC levels did not change during the sampling season, while ETN levels increased in later samples (S3-S6) and nitriles only displayed increased levels in S4 (Figure 3B). In organic white cabbages from $\mathrm{ORG}_{1}$, cabbages from the first sampling date (S1) released with up to $0.96 \pm 0.14 \mu \mathrm{mol} / \mathrm{g}$ FW mainly ITCs, which was generally the highest observed ITC level in white cabbages. On the other hand, samples S3, S5, and S6 only showed low levels of ITC formation $(0.02-0.06 \mu \mathrm{mol} / \mathrm{g} \mathrm{FW})$ with nitriles and ETNs as the most dominant GLS-hydrolysis products (Figure 3C).

Red cabbages from the first samples (S1-S3) usually mainly released ITCs, while later samples (S3-S6) mainly released nitriles or ETNs (Figure 3D-F). More specifically, the total ITC formation was highest in the first samples and peaked in cabbages from $\mathrm{S} 1\left(\mathrm{CON}_{1}\right.$ and $\left.\mathrm{CON}_{2}\right)$ or $\mathrm{S} 2\left(\mathrm{ORG}_{1}\right)$, while later samples released much lower total ITCs (Figure 3D-E). In red cabbages from $\mathrm{CON}_{1}$, ETNs and nitriles displayed increased levels in S5 and S6 cabbages compared to S1-S4 (Figure 3D). Comparably, in $\mathrm{CON}_{2}$, the red cabbages total ETN formation was also higher in $\mathrm{S} 5$, but nitriles were not affected (Figure 3E). In organic red cabbages from $\mathrm{ORG}_{1}$, total nitriles were also highest in S5, while ETN-formation fluctuated and displayed increased levels in S2 and S5 compared to S3 and S6 (Figure 3F). 
A)

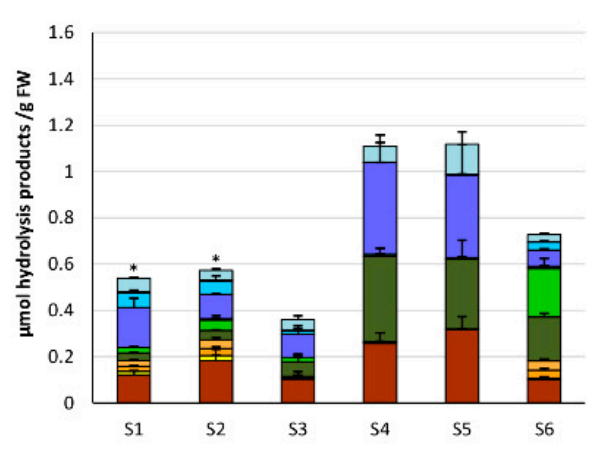

D)

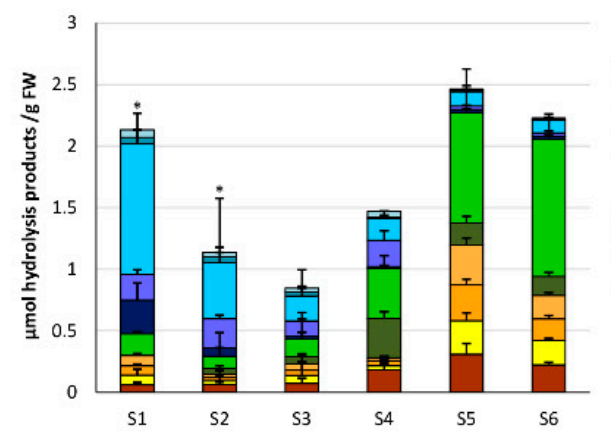

B)



E)

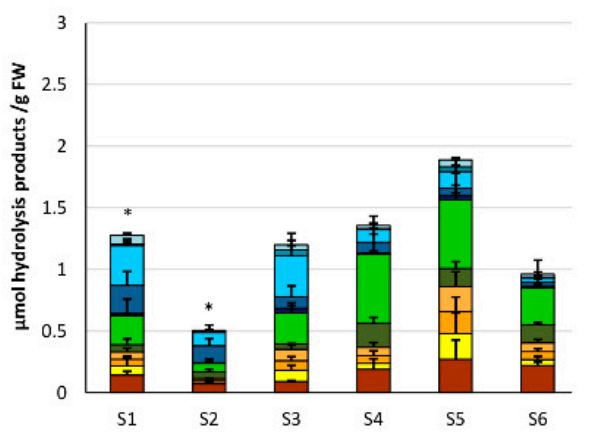

C)

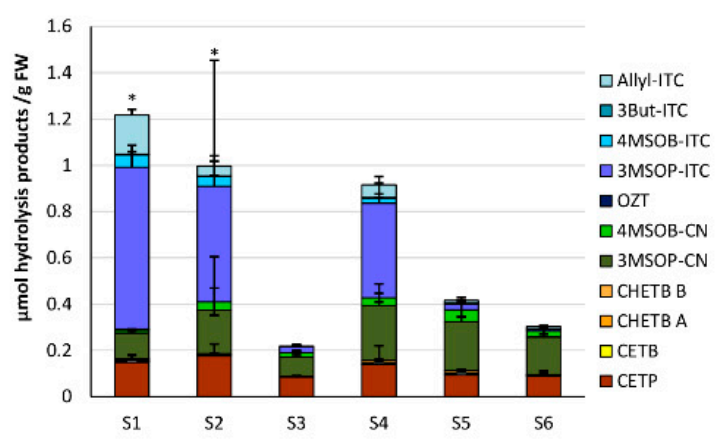

F)



Figure 2. Main glucosinolate (GLS) hydrolysis products released from white $(\mathbf{A}-\mathbf{C})$ and red cabbages (D-F) from conventional $(\mathbf{A}, \mathbf{B}, \mathbf{D}, \mathbf{E})$ and organic supermarkets $(\mathbf{C}, \mathbf{F})$ on different sampling dates (S1-S6). Exact sampling dates can be found in Table 1. (A,D) Represent conventional supermarket $1\left(\mathrm{CON}_{1}\right),(\mathbf{B}, \mathbf{E})$ stand for conventional supermarket $2\left(\mathrm{CON}_{2}\right)$, and $(\mathbf{C}, \mathbf{F})$ show results from organic supermarket $1\left(\mathrm{ORG}_{1}\right)$. Each color in the bar of the given bar chart represents the mean plus standard deviation (SD) of the GLS hydrolysis products from three cabbage heads from the same supermarket $(n=3)$. Abbreviations: FW: Fresh weight; abbreviations of compounds are listed in Table 3. * Samples were analyzed from $1 \mathrm{~g}$ of sample homogenate (instead of $0.5 \mathrm{~g}$ ). 
A)



D)

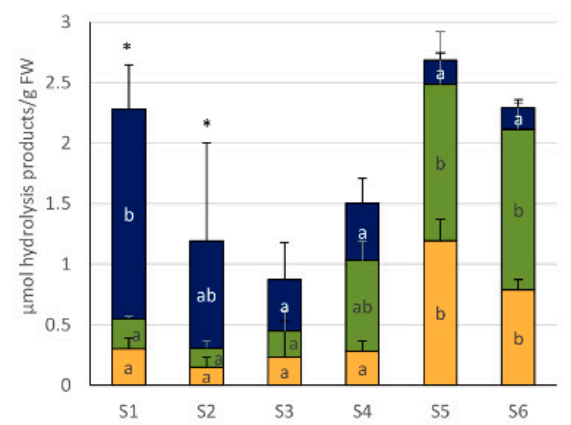

B)

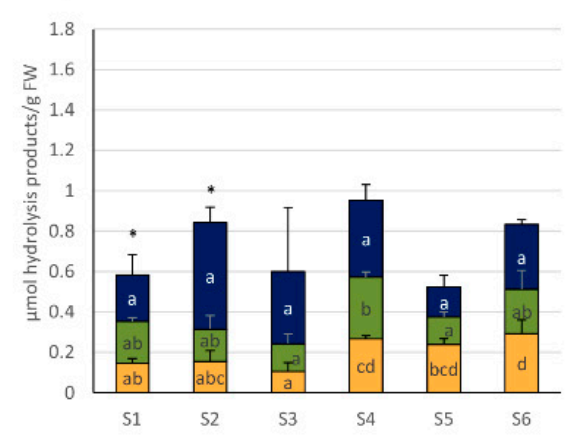

E)

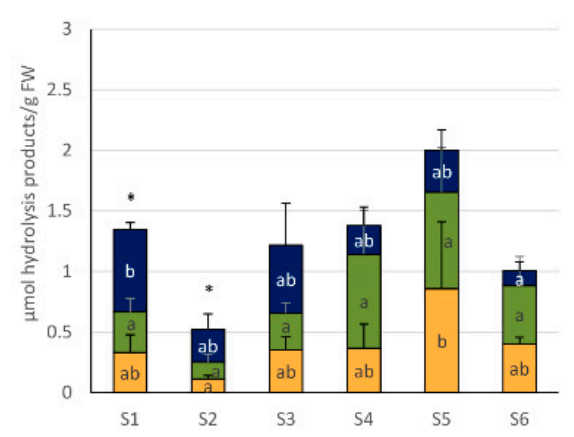

C)

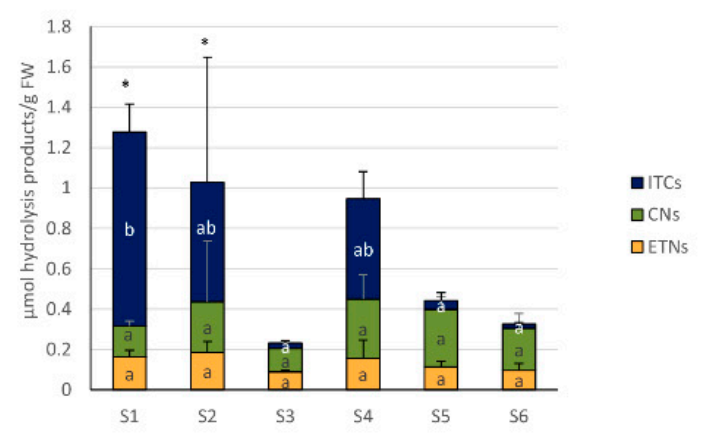

F)

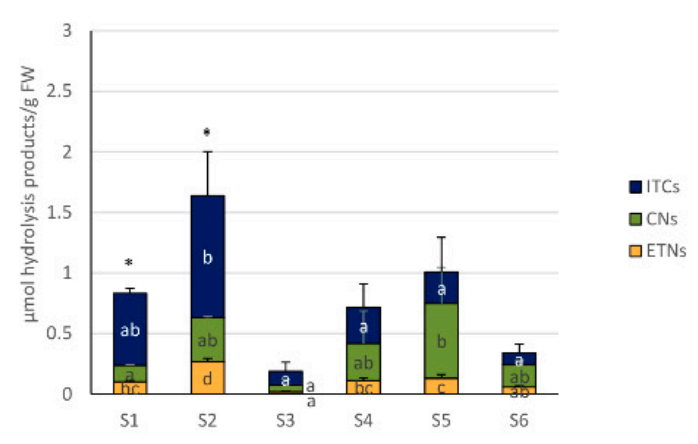

Figure 3. Formation of total isothiocyanates (ITCs), nitriles (CNs), and epithionitriles (ETNs) from white (A-C) and red cabbages (D-F) from conventional (A,B,D,E) and organic supermarkets (C,F) on different sampling dates (S1-S6). Exact sampling dates can be found in Table 1. (A,D) Represent conventional supermarket 1 $\left(\mathrm{CON}_{1}\right),(\mathbf{B}, \mathrm{E})$ stand for conventional supermarket $2\left(\mathrm{CON}_{2}\right)$, and $(\mathbf{C}, \mathbf{F})$ show results from organic supermarket $1(\mathrm{ORG})$. Each color in the bar of the given bar chart represents the mean minus standard deviation (SD) of the total ITC, CN, or ETN levels from three cabbage heads from the same supermarket $(n=3)$. Different lower case letters indicate significant differences in means between total ITCs, CNs, and ETNs levels in different samples, as tested by ANOVA and Tukey's HSD test at the $p \leq 0.05$ level. FW: Fresh weight. * Samples were analyzed from $1 \mathrm{~g}$ of sample homogenate (instead of $0.5 \mathrm{~g}$ ). 
Regarding the ratios (\%) of total EPTs, nitriles, and ITCs relative to the total amount of formed GLS hydrolysis products, usually the relative ITC formation was higher in the first samples of cabbages, where they were often the main GLS hydrolysis products, but ITC formation decreased towards later sampling dates. Relative nitrile formation often behaved the other way around and was higher in later samples compared to early samples (Figure 4). More specifically, in white cabbages from $\mathrm{CON}_{1}$, the $\%$ of ITCs more than halved, while relative nitrile levels more than tripled from S1 to S6 and relative ETN formation was slightly increased in S2 compared to the other samples (Figure 4A). In white cabbages from $\mathrm{CON}_{2}$, the relative ITC formation was highest in S2 with $63 \pm 11 \%$ and then decreased to S5 by $56 \%$ to $28 \pm 9 \%$ of ITC formation. While relative nitrile formation was hardly affected, relative ETN formation increased from S1 to S5 to $46 \pm 10 \%$ of ETN formation in S5 (Figure 4B). In organic white cabbages from $\mathrm{ORG}_{1}$, GLSs also mainly released ITCs with $75 \pm 3 \%$ in S1, while cabbages from later samples (S3, S5, and S6) mainly released nitriles with up to $65 \pm 7 \%$ (in S5) (Figure 4C). Red cabbages showed a very similar GLS hydrolysis behavior: With up to $75 \pm 7 \%$ of ITC formation (S1 from $\mathrm{CON}_{1}$ ) the first samples (S1-S3) released mainly ITCs and the formation decreased towards later sampling dates, while nitrile formation increased in reverse with later samples to up to $64 \pm 8 \%$ (S5 from $\mathrm{ORG}_{1}$ ).

The relative ETN release was not affected in red cabbages from $\mathrm{CON}_{2}$ and $\mathrm{ORG}_{1}$, but increased with later samples in $\mathrm{CON}_{1}$ up to $45 \pm 9 \%$ of all GLS products (in S5) (Figure $4 \mathrm{D}-\mathrm{F}$ ). As an indicator of ESP-activity, the relative formation of CETP, Allyl-ITC, and Allyl-CN were monitored, as well. In red cabbages from $\mathrm{CON}_{1}$ and $\mathrm{ORG}_{1}$, the relative release of CEPT increased from first to last samples, while in white cabbages, an increase from S1 to S2-S5 was found (Supplemental Figure S1). The relative CETP formation was unaffected in red cabbages from $\mathrm{CON}_{2}$ and conventional white cabbages. 
A)

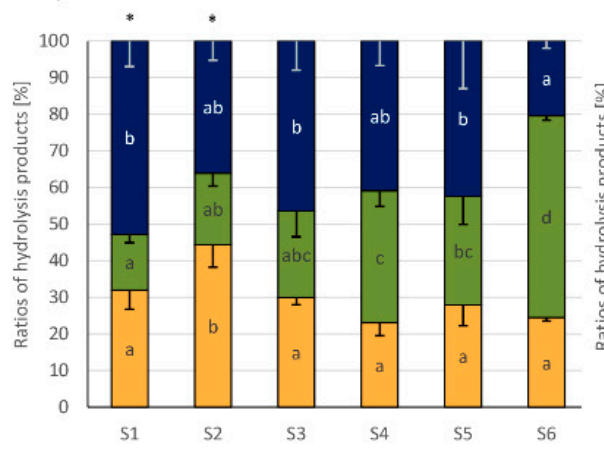

D)

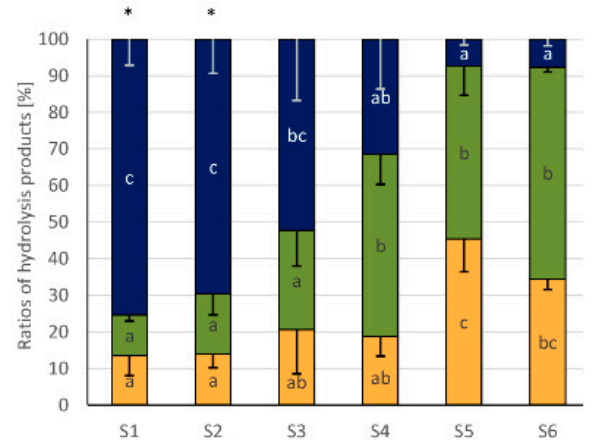

B)



E)

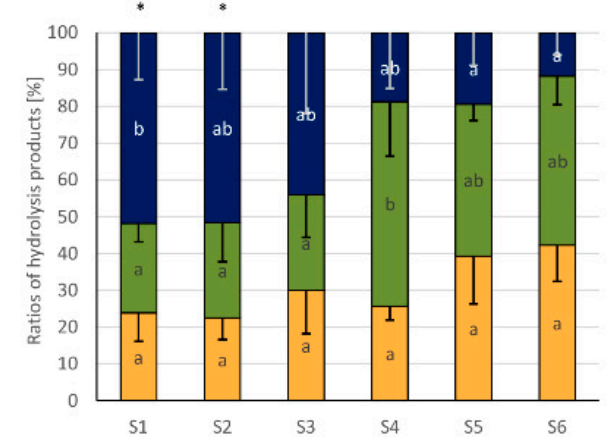

C)

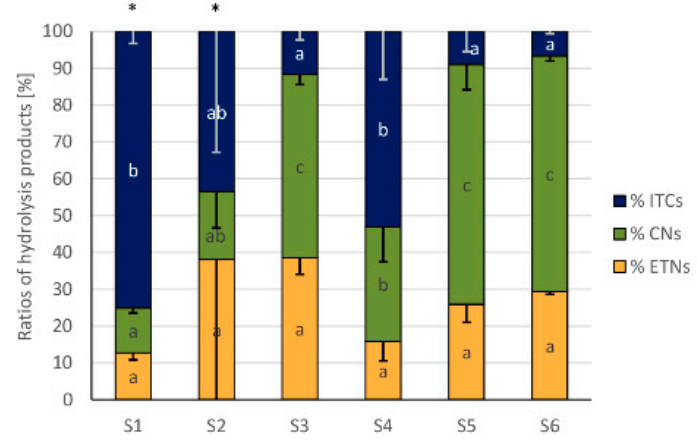

F)

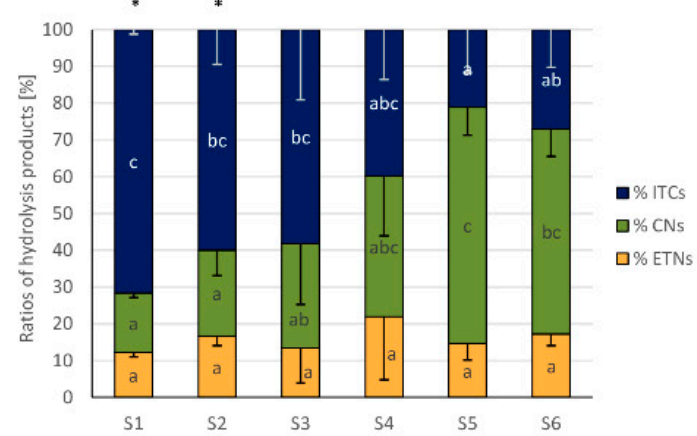

Figure 4. Total glucosinolate (GLS) hydrolysis product ratios (percentage of total isothiocyanates (ITCs), nitriles (CNs), and epithionitriles (ETNs)) from white (A-C) and red cabbages (D-F) from conventional (A,B,D,E) and organic supermarkets (C,F) on different sampling dates (S1-S6). Exact sampling dates can be found in Table 1. $(\mathbf{A}, \mathbf{D})$ Represent conventional supermarket $1\left(\mathrm{CON}_{1}\right),(\mathbf{B}, \mathbf{E})$ stand for conventional supermarket $2\left(\mathrm{CON}_{2}\right)$, and $(\mathbf{C}, \mathbf{F})$ show results from organic supermarket 1 $\left(\mathrm{ORG}_{1}\right)$. Each color in the bar of the given bar chart represents the mean minus standard deviation (SD) of the GLS hydrolysis products from three cabbage heads from the same supermarket $(n=3)$. Different lower case letters indicate significant differences in means between the ratios of total ITCs, CNs, and ETNs in different samples, as tested by ANOVA and Tukey's HSD test at the $p \leq 0.05$ level. FW: Fresh weight. * Samples were analyzed from $1 \mathrm{~g}$ of sample homogenate (instead of $0.5 \mathrm{~g}$ ). 


\subsection{Glucosinolates and Glucosinolate Hydrolysis Products Formation in Freshly Harvested White and Red Cabbages}

The GLS profile of freshly harvested white and red cabbages was similar to the commercial ones, and 3MSOP and Allyl were most dominant in white cabbage (Figure 5A), whilst 2OH3But and 4MSOB contributed the most towards the total GLS content of freshly harvested red cabbage (Figure 5D). The total GLS and GLS-hydrolysis product level of red cabbages was higher compared to the freshly harvested white cabbages. With regard to individual GLS hydrolysis product formation, the main GLS hydrolysis products released from homogenized freshly harvested white cabbages were CETP and 3MSOP-CN (Figure 5B) and from freshly harvested red cabbages 4MSOB-CN and 4MSOB-ITC (Figure 5E). Of the detected GLS hydrolysis products from freshly harvested white cabbages, $36 \pm 13 \%$ were nitriles (mainly $3 \mathrm{MSOP}-\mathrm{CN}$ ), $34 \pm 7 \%$ were ETNs, and $30 \pm 9 \%$ were ITCs (Figure $5 \mathrm{C}$ ), while in red cabbages GLSs were degraded to $52 \pm 3 \%$ nitriles (mainly 4 MSOB-CN), $28 \pm 2 \%$ ETNs, and $20 \pm 4 \%$ ITCs (Figure 5F).

A)

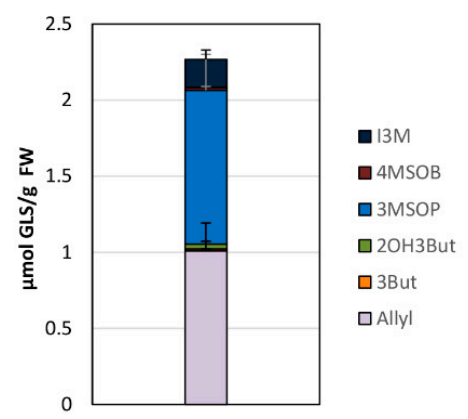

D)

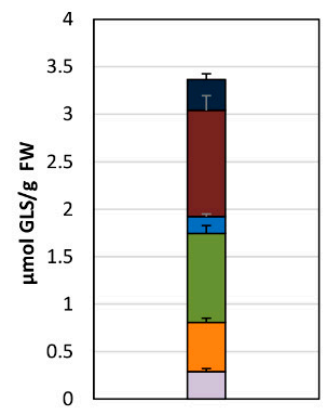

B)

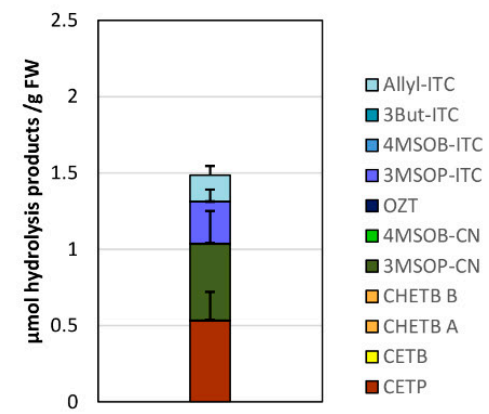

E)

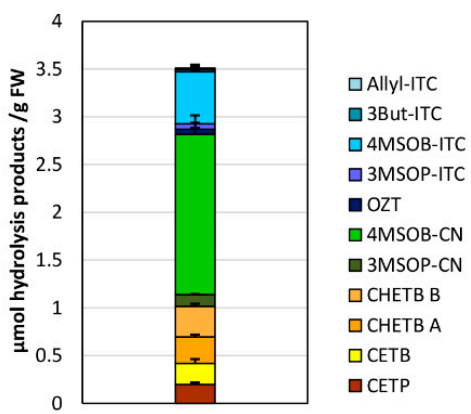

C)

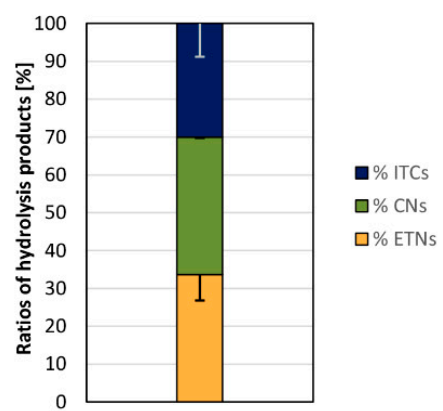

F)

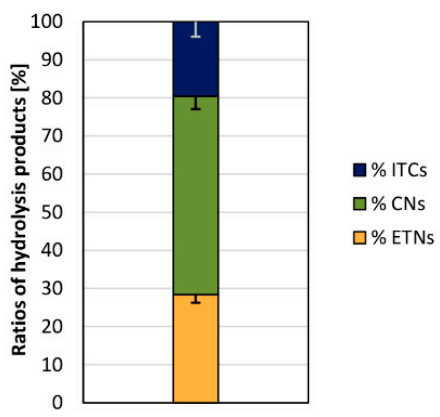

Figure 5. Glucosinolate (GLS) $(\mathbf{A}, \mathbf{D})$ and their absolute $(\mathbf{B}, \mathbf{E})$ and relative $(\mathbf{C}, \mathbf{F})$ hydrolysis product formation in white $(\mathbf{A}-\mathbf{C})$ and red cabbages $(\mathbf{D}-\mathbf{F})$ harvested freshly from the field. Each color in the bar of the given bar chart represents the mean plus standard deviation (SD) of the GLS (A,D), their respective hydrolysis products $(\mathbf{B}, \mathbf{E})$, or the ratio of relative isothiocyanates (ITCs), nitriles (CNs), and epithionitriles (ETNs) $(\mathbf{C}, \mathbf{F})$ from three cabbage heads freshly harvested from the field $(n=3)$. Abbreviations: FW: Fresh weight; abbreviations of compounds are listed in Table 3.

\section{Discussion}

In this study, the GLS content and formation of GLS hydrolysis products was evaluated in commercial white and red cabbages purchased from two conventional and one organic supermarket in Germany over a period of 3 months and compared to freshly harvested cabbages. In general, the composition of individual GLSs in red and white cabbages among different food retailers displayed only slight fluctuations and the GLS profile and levels were similar over the six sampling periods (Figure 1). With Allyl and 3MSOP being the main GLS in commercial and freshly harvested white cabbages and red cabbages being rich in 4MSOB and 2OH3But, (but also of Allyl, 3But, 3MSOP, and I3M), the GLS profiles and levels were in accordance to previous reports [14,24]. The small 
variability in GLS levels is an unexpected observation, as the analyzed white and red cabbages differed in genotype, came from different regions, were cultivated on different soil types using different fertilizers and storage practices, and were also purchased from different food retailers that belonged to different food trading companies (Table 2, Supplemental Table S1). Previous studies showed that GLS levels in Brassica oleracea vegetables are affected by cultivar (genotype) [14,25], nutrient supply [26,27], climatic conditions $[17,20,28]$, as well as storage conditions $[29,30]$. As the variability of the GLSs was relatively low, it is suspected that genotypes were similar in their initial GLS concentrations and that also cultivation practices and storage conditions had no major effect on the GLS content of the cabbages, when they were finally sold in the supermarket. On the other hand, long-term storage $\left(2{ }^{\circ} \mathrm{C}, 95 \%\right.$ of relative humidity, up to 100 days) was shown to decrease the GLS content in Chinese cabbage (Brassica rapa L. spp. pekinensis), with GLSs being more stable in cabbages stored under a controlled atmosphere (CA) $\left(2 \% \mathrm{O}_{2}\right.$ and $\left.2 \% \mathrm{CO}_{2}\right)$ [31]. Accordingly, Osher et al. (2018) even reported an increase for aliphatic ITC-formation in cabbage (B. oleracea) stored at $1{ }^{\circ} \mathrm{C}$ under CA for 60 days (CA: $2 \% \mathrm{O}_{2}, 5 \% \mathrm{CO}_{2}$ ), while ITC formation declined when stored under normal atmosphere (up to 45 and $72 \%$ decline in Allyl-ITC after 60 and 90 days, respectively) [32]. In the present study, I3M levels of organic white and red cabbages from $\mathrm{ORG}_{1}$ were often higher, compared to the cabbages from the conventional food retailers $\mathrm{CON}_{1}$ and $\mathrm{CON}_{2}$ (Figure 1C). Likewise, using NMR spectroscopy, Lucarini et al. (2020) recently also found nearly 3 times as much I3M in organic broccoli compared to conventionally grown ones [33]. In that study, the main difference in both farming practices was the fertilization practice, as no pesticides were used. While the same amount of nitrogen was supplied to the soil, for conventional broccoli with $0.2 \mathrm{t} /$ ha urea and $15 \mathrm{t} /$ ha bovine manure were applied, while organic grown broccoli was fertilized with $28 \mathrm{t} / \mathrm{ha}$ [33]. Nevertheless, increased I3M biosynthesis could be also explained due to the absence of chemical pesticides in organic cultivation practices, resulting in the stimulation of indole GLS biosynthesis upon herbivory damage via the methyl jasmonate signalling pathway [34].

Upon homogenization, GLSs were hydrolyzed in cabbages, yielding nitriles, ITC (or breakdown product thereof), and ETNs. Usually, the recovery of aliphatic GLS hydrolysis products was good with recoveries in a range of $60-130 \%$. However, in some samples, low recoveries of aliphatic GLS hydrolysis samples were also observed (for example, S3 and S6 white cabbage samples and the S3 red cabbage sample from $\mathrm{ORG}_{1}$ ) (Figures 1 and 2). Regarding this observation, myrosinase activity in these samples was probably low, therefore, resulting in a low recovery of hydrolysis products. In pre-experiments performed for the current study, the recovery of GLS hydrolysis products did not benefit from longer incubation times. Probably due to chemical instabilities of the products $[35,36]$, it is likely that the myrosinase activity decreases with incubation time and that the initial myrosinase activity might be a major factor for the recovery of products. This hypothesis is further supported by the observation that sulfate, which is released during GLS hydrolysis, is a competitive inhibitor of myrosinase activity [37].

With regard to the differences in GLS hydrolysis products in the different samples, in contrast to GLS, the formation of GLS hydrolysis products varied strongly between the purchase dates (S1-S6; Figure 2). Especially during the first samples (S1-S3) mainly ITCs were released from red cabbages, while in later samples nitriles were preferentially formed (S5, S6) (Figure 3). Likewise, the relative ITC formation in white and red cabbages generally decreased until the last sample, while nitriles were usually the major hydrolysis products (Figure 4). These results show that in contrast to some previous reports [14,38], ITCs can be the main hydrolysis products in cabbages, as this was the case for cabbages purchased in early autumn. Here, red cabbage could be an excellent source for cancer-preventive 4MSOB-ITC (sulforaphane) (up to $1.06 \mu \mathrm{mol} / \mathrm{g} \mathrm{FW}$ in red cabbage from $\mathrm{CON}_{1}$ at S1), releasing levels, which were 6-times higher compared to mature broccoli and comparable to the 4MSOB-ITC release from broccoli sprouts [14].

With regard to the high nitrile and ETN formation at later purchase dates, the ESP protein activity is made responsible for ETN-release from alkenyl GLS and for increased formation in simple nitriles 
from non-alkenyl GLS [39,40]. Therefore, it was suspected that the ESP-activity increased towards later samples, while it remained low in the first samples. When regarding the relative formation of Allyl hydrolysis products, as an indicator of ESP activity, it can be further supported that the ESP activity increased with later purchase dates in red cabbage from $\mathrm{CON}_{1}$ and organic cabbage, while it was not considerably affected in conventional white cabbage (Figure S1). As the relative nitrile formation significantly increased in white cabbage from $\mathrm{CON}_{1}$ in later samples (Figure $4 \mathrm{~A}$ ) (but relative CETP release not, Figure S1), it is suspected, that next to the ESP activity, also other factors influence GLS hydrolysis, which could have resulted in changes in hydrolysis product behavior from S1 to S6 due to their variation. As especially nitriles increased (Figure 4A), it is suspected that white cabbage contains nitrile specifier proteins, which are involved in nitrile formation in Arabidopsis thaliana [41]. This suspicion is strengthened by the observation that Brassica oleracea contains a gene with a homology of $80 \%$ compared to the nitrile specifier protein 1 of $A$. thaliana [42]. Further, this hypothesis is supported by a recent study, which could neither prove the nitrile specifier protein activity for three B. oleracea ESP isoforms in vitro nor in vivo, but nitrile formation from alkyl GLS was observed [43].

To date, there is little data how pre- and postharvest factors affect glucosinolate hydrolysis. Freshly harvested white and red cabbages showed a similar GLS hydrolysis behavior compared to the supermarket cabbages purchased during similar dates (S5 white cabbage, S4 red cabbage) (Figure 5; Figures 2-4). Due to this finding and due to the different storage conditions of growers and retailers, in the present study storage does not seem to be the factor that caused a reduced ITC release in cabbages purchased in later autumn. With regard to preharvest factors, nitrogen and sulfur supply affected the release of GLS hydrolysis products in the ETN-producer Chinese cabbage (Brassica rapa L. ssp. pekinensis) and ITCs were reduced in response to the increasing $\mathrm{N}$ and decreasing $\mathrm{S}$ supply [44]. In pak choi (B. rapa subsp. chinensis (L.) Hanelt), which also mainly released ETN, the ITC/CN and ITC/ETN ratio increased with the increasing sulfur supply [45]. With regard to the present study, it is unlikely that differences in fertilization were responsible for the observed changes in the GLS hydrolysis behavior as also the red cabbage from $\mathrm{CON}_{2}$ which originated from the same grower (Table 2, Table S1) showed reduced \% ITC release at later purchase dates (Figure 4E). Moreover, herbivore feeding can affect the GLS hydrolysis behavior, and simple nitrile formation was shown to increase in response to the specialist insect feeding (Pieris rapae) in Arabidopsis thaliana Col-0 [46], while ITC-emitting plants appear to be better defended against generalist herbivores [47]. However, as organic and conventional cabbages displayed a similar hydrolysis behavior (Figure 4D-F), it is suspected that climatic conditions such as reduced radiation or decreasing temperatures across the autumn season might be responsible for the observed shifts. Moreover, all of the conventional cabbages originated from the Dithmarschen region (Schleswig-Holstein, Germany; Table S1), which is characterized by a coastal climate and marsh soil (being ideal conditions for growing cabbages). It is the largest coherent cabbage-growing area in Europe. In Table S4, the climatic data of the presumable growing season in 2019 is presented. Consequently, it is likely that temperature and radiation interact with regard to the GLS hydrolysis behavior. Recently, Jasper et al. (2020) showed that at higher temperatures during growth, more GLS hydrolysis products were formed from rocket (Eruca sativa), while GLS levels were less affected [48]. Likewise, Ku et al. (2013) reported different ITC conversion rates in broccoli grown in 2 different years and linked this to different climatic conditions. Unfortunately, in that study, nitriles were not analyzed and therefore, conversion rates could have been also affected by changes of the myrosinase activity [49]. As organic cabbages which originated from different regions in Germany (Brandenburg, Mecklenburg-Western Pomerania, Schleswig-Holstein; Table 2 and Table S1) also showed similar changes in the GLS hydrolysis behavior compared to the conventional cabbages originating from the Dithmarschen region, it can be assumed that the results obtained in this study might be also valid for other countries and regions with similar climatic conditions. The specific role of climatic growth conditions on GLS hydrolysis in B. oleracea vegetables will need to be evaluated in future studies. 


\section{Conclusions}

Current findings in this study have highlighted the great diversity, particularly of the GLS hydrolysis behavior in white and red cabbages between the different supermarkets over the six sampling periods: Whilst the GLS composition and content remained similar between the different food retailers, the composition and content of the individual hydrolysis products formed varied across the season and high ITC levels were generally noted in early sampling periods (early September) and decreased, particularly in red cabbages over time. Here, the increased specifier protein activity is made responsible for the reduced ITC-release.

In conclusion, with regard to their potential to release more ITCs, consumption of commercial cabbages purchased in early autumn could be healthier options than those purchased in later autumn months. The fact that ITCs can be preferentially formed in earlier autumn months, but hardly towards the end of autumn, underlines the need to unravel the factors that affect the GLS-hydrolysis outcome. The results of this study might also help growers and food companies produce cabbages and products with more pungency due to a higher ITC formation. Due to the potential of red cabbage to form high rates of health-promoting 4MSOB-ITC in cabbages purchased in early autumn, red cabbage consumption could be an alternative for people who dislike broccoli.

Supplementary Materials: The following are available online at http:/www.mdpi.com/2304-8158/9/11/1682/ s1, Figure S1: Allyl glucosinolate hydrolysis product ratios [percentage of allyl isothiocyanate (Allyl-ITC), 3-butenenitrile (Allyl-CN) and 1-cyano-2,3-epithiopropane (CETP)] from white (A-C) and red cabbages (D-F) from conventional (A, B, D, E) and organic supermarkets (C, F) on different sampling dates (S1-S6). Table S1: Overview of white and red cabbages purchased from three different food retailers or harvested freshly from the field (Großbeeren, D). Table S2: Glucosinolates (GLSs) content in commercial and cabbages harvested freshly from the field in $\mu \mathrm{mol} / \mathrm{g}$ fresh weight. Table S3: Glucosinolate (GLS) hydrolysis product formation in commercial and cabbages harvested freshly from the field in $\mu \mathrm{mol} / \mathrm{g}$ fresh weight. Table S4: Climatic data of the Dithmarschen region in northern Germany in 2019.

Author Contributions: Conceptualization, N.S.W., F.S.H., and S.R.; methodology, N.S.W. and F.S.H.; validation, F.S.H.; investigation, N.S.W. and F.S.H.; resources, F.S.H.; writing —original draft preparation, N.S.W. and F.S.H.; writing - review and editing, F.S.H. and S.R.; visualization, N.S.W. and F.S.H.; supervision, F.S.H. and S.R.; project administration, F.S.H.; funding acquisition, F.S.H. All authors have read and agreed to the published version of the manuscript.

Funding: Franziska Hanschen and this research study are part of the Leibniz-Junior Research Group OPTIGLUP, funded by the Leibniz-Association (J16/2017).

Acknowledgments: The excellent technical assistance of Andrea Jankowsky, Andrea Maikath, and Jessica Eichhorn is gratefully acknowledged.

Conflicts of Interest: The authors declare no conflict of interest.

\section{References}

1. BMEL-Bundesministerium für Ernährung und Landwirtschaft. Available online: https://www.bmel-statistik. de/fileadmin/daten/GBT-0070004-2018.pdf (accessed on 15 July 2020).

2. Blažević, I.; Montaut, S.; Burčul, F.; Olsen, C.E.; Burow, M.; Rollin, P.; Agerbirk, N. Glucosinolate structural diversity, identification, chemical synthesis and metabolism in plants. Phytochemistry 2020, 169, 112100. [CrossRef] [PubMed]

3. Katsarou, D.; Omirou, M.; Liadaki, K.; Tsikou, D.; Delis, C.; Garagounis, C.; Krokida, A.; Zambounis, A.; Papadopoulou, K.K. Glucosinolate biosynthesis in Eruca sativa. Plant Physiol. Biochem. 2016, 109, 452-466. [CrossRef] [PubMed]

4. Hanschen, F.S.; Lamy, E.; Schreiner, M.; Rohn, S. Reactivity and stability of glucosinolates and their breakdown products in foods. Angew. Chem. Int. Ed. 2014, 53, 11430-11450. [CrossRef]

5. Bell, L.; Oloyede, O.O.; Lignou, S.; Wagstaff, C.; Methven, L. Taste and flavor perceptions of glucosinolates, isothiocyanates, and related compounds. Mol. Nutr. Food Res. 2018, 62, e1700990. [CrossRef] [PubMed]

6. Koroleva, O.A.; Cramer, R. Single-cell proteomic analysis of glucosinolate-rich S-cells in Arabidopsis thaliana. Methods 2011, 54, 413-423. [CrossRef] 
7. Wittstock, U.; Burow, M. Glucosinolate breakdown in Arabidopsis: Mechanism, regulation and biological significance. Arab. Book 2010, 8, e0134. [CrossRef]

8. Palliyaguru, D.L.; Yuan, J.-M.; Kensler, T.W.; Fahey, J.W. Isothiocyanates: Translating the power of plants to people. Mol. Nutr. Food Res. 2018, 62, e1700965. [CrossRef]

9. Romeo, L.; Iori, R.; Rollin, P.; Bramanti, P.; Mazzon, E. Isothiocyanates: An overview of their antimicrobial activity against human infections. Molecules 2018, 23, 624. [CrossRef]

10. Chou, Y.-C.; Chang, M.-Y.; Lee, H.-T.; Shen, C.-C.; Harnod, T.; Liang, Y.-J.; Wu, R.S.-C.; Lai, K.; Hsu, F.; Chung, J.-G. Phenethyl isothiocyanate inhibits in vivo growth of xenograft tumors of human glioblastoma cells. Molecules 2018, 23, 2305. [CrossRef]

11. Veeranki, O.L.; Bhattacharya, A.; Tang, L.; Marshall, J.R.; Zhang, Y. Cruciferous vegetables, isothiocyanates, and prevention of bladder cancer. Curr. Pharmacol. Rep. 2015, 1, 272-282. [CrossRef]

12. Hanschen, F.S.; Herz, C.; Schlotz, N.; Kupke, F.; Rodríguez, M.M.B.; Schreiner, M.; Rohn, S.; Lamy, E. The Brassica epithionitrile 1-cyano-2,3-epithiopropane triggers cell death in human liver cancer cells in vitro. Mol. Nutr. Food Res. 2015, 59, 2178-2189. [CrossRef] [PubMed]

13. Matusheski, N.V.; Jeffery, E. Comparison of the bioactivity of two glucoraphanin hydrolysis products found in broccoli, sulforaphane and sulforaphane nitrile. J. Agric. Food Chem. 2001, 49, 5743-5749. [CrossRef] [PubMed]

14. Hanschen, F.S.; Schreiner, M. Isothiocyanates, nitriles, and epithionitriles from glucosinolates are affected by genotype and developmental stage in Brassica oleracea varieties. Front. Plant Sci. 2017, 8, 1095. [CrossRef] [PubMed]

15. Klopsch, R.; Witzel, K.; Börner, A.; Schreiner, M.; Hanschen, F.S. Metabolic profiling of glucosinolates and their hydrolysis products in a germplasm collection of Brassica rapa turnips. Food Res. Int. 2017, 100, $392-403$. [CrossRef]

16. Verkerk, R.; Schreiner, M.; Krumbein, A.; Ciska, E.; Holst, B.; Rowland, I.; De Schrijver, R.; Hansen, M.; Gerhäuser, C.; Mithen, R.; et al. Glucosinolates in Brassica vegetables: The influence of the food supply chain on intake, bioavailability and human health. Mol. Nutr. Food Res. 2008, 53, S219. [CrossRef]

17. Cartea, M.E.; Velasco, P.; Obregón, S.; Padilla, G.; De Haro, A. Seasonal variation in glucosinolate content in Brassica oleracea crops grown in northwestern Spain. Phytochemistry 2008, 69, 403-410. [CrossRef]

18. Rosa, E.A.; Rodrigues, A.S. Total and individual glucosinolate content in 11 broccoli cultivars grown in early and late seasons. HortScience 2001, 36, 56-59. [CrossRef]

19. Nuñez-Gómez, V.; Baenas, N.; Navarro-González, I.; García-Alonso, F.J.; Moreno, D.A.; González-Barrio, R.; Periago, M.J. Seasonal variation of health-promoting bioactives in broccoli and methyl-jasmonate pre-harvest treatments to enhance their contents. Foods 2020, 9, 1371. [CrossRef] [PubMed]

20. Charron, C.S.; Sams, C.E. Glucosinolate content and myrosinase activity in rapid-cycling Brassica oleracea grown in a controlled environment. J. Am. Soc. Hortic. Sci. 2004, 129, 321-330. [CrossRef]

21. Mølmann, J.A.; Steindal, A.L.; Bengtsson, G.B.; Seljåsen, R.; Lea, P.; Skaret, J.; Johansen, T.J. Effects of temperature and photoperiod on sensory quality and contents of glucosinolates, flavonols and vitamin $\mathrm{C}$ in broccoli florets. Food Chem. 2015, 172, 47-55. [CrossRef]

22. Pereira, F.M.V.; Rosa, E.; Fahey, J.W.; Stephenson, K.K.; Carvalho, R.; Aires, A. Influence of temperature and ontogeny on the levels of glucosinolates in nroccoli (Brassica oleracea var. italica) sprouts and their effect on the induction of mammalian phase 2 enzymes. J. Agric. Food Chem. 2002, 50, 6239-6244. [CrossRef] [PubMed]

23. Hanschen, F.S. Domestic boiling and salad preparation habits affect glucosinolate degradation in red cabbage (Brassica oleracea var. capitata f. rubra). Food Chem. 2020, 321, 126694. [CrossRef] [PubMed]

24. Ciska, E.; Martyniak-Przybyszewska, B.; Kozlowska, H. Content of glucosinolates in cruciferous vegetables grown at the same site for two years under different climatic conditions. J. Agric. Food Chem. 2000, 48, 2862-2867. [CrossRef]

25. Brown, A.F.; Yousef, G.G.; Jeffery, E.H.; Klein, B.P.; Wallig, M.A.; Kushad, M.M.; Juvik, J.A. Glucosinolate profiles in broccoli: Variation in levels and implications in breeding for cancer chemoprotection. J. Am. Soc. Hortic. Sci. 2002, 127, 807-813. [CrossRef]

26. Schonhof, I.; Blankenburg, D.; Müller, S.; Krumbein, A. Sulfur and nitrogen supply influence growth, product appearance, and glucosinolate concentration of broccoli. J. Plant Nutr. Soil Sci. 2007, 170, 65-72. [CrossRef] 
27. Omirou, M.D.; Papadopoulou, K.K.; Papastylianou, I.; Constantinou, M.; Karpouzas, D.G.; Asimakopoulos, I.; Ehaliotis, C. Impact of nitrogen and sulfur fertilization on the composition of glucosinolates in relation to sulfur assimilation in different plant organs of broccoli. J. Agric. Food Chem. 2009, 57, 9408-9417. [CrossRef]

28. Charron, C.S.; Saxton, A.M.; Sams, C.E. Relationship of climate and genotype to seasonal variation in the glucosinolate-myrosinase system. I. Glucosinolate content in ten cultivars of Brassica oleracea grown in fall and spring seasons. J. Sci. Food Agric. 2005, 85, 671-681. [CrossRef]

29. Vallejo, F.; Tomás-Barberán, F.; García-Viguera, C. Health-promoting compounds in broccoli as influenced by refrigerated transport and retail sale period. J. Agric. Food Chem. 2003, 51, 3029-3034. [CrossRef]

30. Rodrigues, A.S.; Rosa, E.A.S. Effect of post-harvest treatments on the level of glucosinolates in broccoli. J. Sci. Food Agric. 1999, 79, 1028-1032. [CrossRef]

31. Kang, J.-H.; Woo, H.-J.; Park, J.-B.; Chun, H.H.; Park, C.W.; Bin Song, K. Effect of storage in pallet-unit controlled atmosphere on the quality of Chinese cabbage (Brassica rapa L. spp. pekinensis) used in kimchi manufacturing. LWT 2019, 111, 436-442. [CrossRef]

32. Osher, Y.; Chalupowicz, D.; Maurer, D.; Ovadia-Sadeh, A.; Lurie, S.; Fallik, E.; Kenigsbuch, D. Summer storage of cabbage. Postharvest Biol. Technol. 2018, 145, 144-150. [CrossRef]

33. Lucarini, M.; Di Cocco, M.E.; Raguso, V.; Milanetti, F.; Durazzo, A.; Lombardi-Boccia, G.; Santini, A.; Delfini, M.; Sciubba, F. NMR-based metabolomic comparison of Brassica oleracea (var. italica): Organic and conventional farming. Foods 2020, 9, 945. [CrossRef] [PubMed]

34. Textor, S.; Gershenzon, J. Herbivore induction of the glucosinolate-myrosinase defense system: Major trends, biochemical bases and ecological significance. Phytochem. Rev. 2008, 8, 149-170. [CrossRef]

35. Hanschen, F.S.; Kaufmann, M.; Kupke, F.; Hackl, T.; Kroh, L.W.; Rohn, S.; Schreiner, M. Brassica vegetables as sources of epithionitriles: Novel secondary products formed during cooking. Food Chem. 2018, 245, 564-569. [CrossRef] [PubMed]

36. Fechner, J.; Kaufmann, M.; Herz, C.; Eisenschmidt, D.; Lamy, E.; Kroh, L.W.; Hanschen, F.S. The major glucosinolate hydrolysis product in rocket (Eruca sativa L.), sativin, is 1,3-thiazepane-2-thione: Elucidation of structure, bioactivity, and stability compared to other rocket isothiocyanates. Food Chem. 2018, 261, 57-65. [CrossRef] [PubMed]

37. Shikita, M.; Fahey, J.W.; Golden, T.R.; Holtzclaw, W.D.; Talalay, P. An unusual case of 'uncompetitive activation' by ascorbic acid: Purification and kinetic properties of a myrosinase from Raphanus sativus seedlings. Biochem. J. 1999, 341, 725-732. [CrossRef] [PubMed]

38. Kyung, K.; Fleming, H.; Young, C.; Haney, C. 1-Cyano-2,3-epithiopropane as the primary sinigrin hydrolysis product of fresh cabbage. J. Food Sci. 1995, 60, 157-159. [CrossRef]

39. Matusheski, N.V.; Swarup, R.; Juvik, J.A.; Mithen, R.; Bennett, M.; Jeffery, E. Epithiospecifier protein from broccoli (Brassica oleracea L. ssp. italica) inhibits formation of the anticancer agent sulforaphane. J. Agric. Food Chem. 2006, 54, 2069-2076. [CrossRef]

40. Burow, M.; Markert, J.; Gershenzon, J.; Wittstock, U. Comparative biochemical characterization of nitrile-forming proteins from plants and insects that alter myrosinase-catalysed hydrolysis of glucosinolates. FEBS J. 2006, 273, 2432-2446. [CrossRef]

41. Wittstock, U.; Meier, K.; Dörr, F.; Ravindran, B.M. NSP-dependent simple nitrile formation dominates upon breakdown of major aliphatic glucosinolates in roots, seeds, and seedlings of Arabidopsis thaliana Columbia-0. Front. Plant Sci. 2016, 7, 1821. [CrossRef]

42. Román, J.; González, D.; Inostroza-Ponta, M.; Mahn, A. Molecular modeling of epithiospecifier and nitrile-specifier proteins of broccoli and their interaction with aglycones. Molecules 2020, 25, 772. [CrossRef] [PubMed]

43. Witzel, K.; Abu Risha, M.; Albers, P.; Börnke, F.; Hanschen, F.S. Identification and characterization of three epithiospecifier protein isoforms in Brassica oleracea. Front. Plant Sci. 2019, 10, 1552. [CrossRef] [PubMed]

44. Geilfus, C.-M.; Hasler, K.; Witzel, K.; Gerendás, J.; Mühling, K.H. Interactive effects of genotype and N/S-supply on glucosinolates and glucosinolate breakdown products in Chinese cabbage (Brassica rapa L. ssp. pekinensis). J. Appl. Bot. Food Qual. 2016, 89, 279-286.

45. Meschede, C.A.C.; Abdalla, M.A.; Mühling, K.H. Sulfur but not nitrogen supply increases the ITC/nitrile ratio in pak choi (Brassica rapa subsp. chinensis (L.) Hanelt). J. Appl. Bot. Food Qual. 2020, 93, 95-104. 
46. Burow, M.; Losansky, A.; Müller, R.; Plock, A.; Kliebenstein, D.J.; Wittstock, U. The genetic basis of constitutive and herbivore-induced ESP-independent nitrile formation in Arabidopsis. Plant Physiol. 2008, 149, 561-574. [CrossRef]

47. Mumm, R.; Burow, M.; Bukovinszkine'Kiss, G.; Kazantzidou, E.; Wittstock, U.; Dicke, M.; Gershenzon, J. Formation of simple nitriles upon glucosinolate hydrolysis affects direct and indirect defense against the specialist herbivore, Pieris rapae. J. Chem. Ecol. 2008, 34, 1311-1321. [CrossRef]

48. Jasper, J.; Wagstaff, C.; Bell, L. Growth temperature influences postharvest glucosinolate concentrations and hydrolysis product formation in first and second cuts of rocket salad. Postharvest Biol. Technol. 2020, 163, 111157. [CrossRef]

49. Ku, K.-M.; Jeffery, E.; Juvik, J.A. Influence of seasonal variation and methyl jasmonate mediated induction of glucosinolate biosynthesis on quinone reductase activity in broccoli florets. J. Agric. Food Chem. 2013, 61, 9623-9631. [CrossRef]

Publisher's Note: MDPI stays neutral with regard to jurisdictional claims in published maps and institutional affiliations.

(C) 2020 by the authors. Licensee MDPI, Basel, Switzerland. This article is an open access article distributed under the terms and conditions of the Creative Commons Attribution (CC BY) license (http://creativecommons.org/licenses/by/4.0/). 